\title{
Of Contracts and the Katallaxy: Measuring the Extent of the Market, 1919-1939
}

JAY COCHRAN, III

jcochra1@gmu.edu

Research Fellow in Regulatory Studies, Mercatus Center, George Mason University, 3301 N. Fairfax Drive, Fourth Floor, Arlington, VA 22201, USA

\begin{abstract}
This paper develops a view of the extent of the market based on the katallactic notions advanced by Mises, Hayek, Buchanan, and others. This contractarian approach to the katallactic process is used to analyze one of the most studied but still controversial periods of U.S. economic history, the interwar years from 1919 to 1939. The pictures that emerge from a katallactic analysis of the interwar years are quite different from those that emerge, for example, from considerations of national income and product. The katallactic approach reveals, for example, that a much larger and more dynamic structure of production and financial exchanges sits behind the relatively sanguine façade of final consumption during this turbulent period.
\end{abstract}

Key Words: great depression, katallactics, measurement

JEL classification: E10, N12.

As it is the power of exchanging that gives occasion to the division of labour, so the extent of this division must always be limited by the extent of that power, or, in other words, by the extent of the market.

—Adam Smith

\section{Introduction}

Smith's observation is a vein rich in economic content. Young (1928), Stigler (1951), Buchanan and Yoon (1994), Levy (1999), and others have successfully mined the Smithian vein, drawing a wealth of important inferences from its implications. ${ }^{1}$ This paper develops a view of the extent of the market based on the katallactic ${ }^{2}$ notions advanced by Mises [1966 (1949)], Hayek (1976), Buchanan (1988), and before them, Whately [1966 (1832)]. Simply put, the katallaxy is the nexus of voluntary exchanges that emerges in a division of labor society based on private ownership of the means of production. ${ }^{3}$ As such, the katallactic approach necessarily places primacy on agreement and is therefore sympathetic with the contractarian analytical paradigm. Moreover, since the contractarian paradigm proceeds from a voluntary foundation, a party to a prospective exchange may agree to a proposed set of exchange terms or not, and if the terms are disagreeable, may exercise an exit option by vacating the proposed exchange, or she may voice her disagreement and attempt to change the contract terms through persuasion. ${ }^{4}$ 
In addition, an exchange orientation allows the economist to step beyond "plutology," or considerations of wealth, and into the world of katallactics or trade. That is, a katallactic orientation shifts the focus from the things being exchanged, to the beings making the exchanges. Katallactics is thus anthropocentric or subjective in that it places emphasis on the individuals who are evaluating and exchanging rather than on the objects of exchange. Of course, katallactics does not obviate the objects of exchange, but instead recognizes that the values assigned to those objects are not intrinsic in the goods themselves, but instead arise at the conjunction of a subject's focused awareness on some object as a means of fulfilling some end. ${ }^{5}$

Specifically, the katallactic or exchange orientation stands in contrast to the more distilled views provided by the national income and product accounts, for example. In drawing such a contrast, however, one should not construe the distinction as taking issue with the formulation or measurement of the national income and product accounts themselves. Indeed, throughout this paper, some components of the national income accounts are used to estimate sub-categories of katallactic activity, and estimates of national income are used as a foil for comparison purposes. Rather, in drawing the contrast, the contention is that measures of national income provide just one, non-exhaustive view into a nation's economy. To rely exclusively on national income for insight, in fact, could be seen as analogous to evaluating a house design just by considering the front elevation of an entire set of house plans. Clearly, the front elevation is an important component of the overall design-in that it shows, for instance, how the house will look to passersby-but it is not all. ${ }^{6}$ When presenting the front elevation of a house, an architect necessarily nets out all of the structural elements and subsystems that sit behind the façade, lest the picture become a jumbled and confusing mess. In much the same way, national income and product accounting nets out many of the behind-the-scenes exchanges (particularly of intermediate goods) that go into creating a given level of value-added goods destined for final consumption. ${ }^{7}$ However, the netting approach of those calculations (undertaken to avoid double counting in terms of value-added), if not carefully kept in mind, can lead some to reverse cause and effect by supposing that the national income determines the volume of economic activity rather than the other way around. Leontief (1936:110), made an especially apt observation in this connection, when he stated:

[The] elimination of doubly counted items means the suppression from our record of all those statistical data which describe the mechanism of inter-industrial relations.

But it is exactly this mechanism which to a large degree determines the size of the net income flow and its variations. ${ }^{8}$

Just as if one wishes a complete understanding of how a house fits together as a building, the floor plans, plumbing and electrical diagrams, and other elevations need to be considered as well. Similarly, if one wishes a more complete understanding of overall economic activity, including the flows of exchange activity that are at its heart, one might also wish to consult other views of economic activity. Leontief offered one such approach with his Input-Output analysis, and before him, Quesnay [1972 (1758)] offered his Tableau Economique, for example. The katallactic approach developed here offers yet another approach to wider analysis of economic activity. ${ }^{9}$ It represents an attempt to look behind the front façade of 
final consumption to see the changes taking place within the structure of production and finance.

This paper uses the interwar years of the United States, 1919-1939, to illustrate how an analysis of katallactic activity can provide insights that other approaches might obscure. The choice of the interwar years flows from the twin observations that, (1) this period of U.S. economic history, though perhaps more widely studied than any other, remains controversial as to its initiating causes and ultimate effects, and (2) by developing a fuller understanding of this turbulent period of economic history, we may gain new insights into economic activity generally that might prove useful in analyzing more recent economic crises. $^{10}$

\section{Of Trades and Transfers}

The katallactic process of reaching agreement (or contracting) and then exchanging contains four critical components that distinguish exchange, as the term appears in this paper, from other forms of economic activity. ${ }^{11}$ First, exchange is an inherently social process involving at least two individuals, each possessing some form of alienable property. Second, exchanges entail reciprocity, or the trading of one value for another. Third, an exchange presupposes agreement and is therefore voluntary at its root. Fourth, a logical implication of the contractarian or voluntary aspect of exchange is an underlying expectation of gains from trade by all parties to a proposed exchange.

Considering these components in further detail, the social aspect of exchange, or the presence of an "other" rules out, for example, what Mises termed "autistic exchange."12 As the term exchange is used here, it means, simply, "the action, or an act, of reciprocal giving and receiving."13 In the context of this paper, one does not meaningfully trade with oneself inasmuch as one already owns the subject property to be "traded" in the first place. Exchange refers here instead to the act of trading ownership of goods among individuals and, therefore, requires both alienable property as well as another person with whom one wishes to trade. Indeed, the social distinction carries practical significance for measuring the extent of the market when one considers, for example, the payment of dividends and entrepreneurial draw ${ }^{14}$ by firms to their owners. As far as the katallaxy is concerned, such payments do not constitute exchanges per se', but instead reflect the voluntary transfer of resources from the control of a firm's managers back to the resources' owners.

Even with the presence of another and alienable property, however, goods can still move among individuals without an exchange occurring if such movement lacks reciprocity. Gifts, for example, typically lack direct reciprocity. This is not to suggest that a giver may not derive some value from the act of giving or that there may not be selfish motives behind a gift. A gift may even involve optimization and choice, but the important distinction remains that most gifts, by their nature, lack a direct, value-for-value exchange that characterizes the reciprocity of the katallactic process. For purposes of this paper, therefore, gifts and bequests are also treated as resource transfers rather than as katallactic activity.

When considering the interactions between the polity and the market, a thorny terminological problem emerges. Are governments' economic activities more like exchanges or transfers? Clearly, an "other" is present in the transactions between the government 
and its citizens, or between government and the suppliers from whom it purchases goods and services. Moreover, in the latter instance, reciprocity may even exist, as might voluntary agreement. In addition, "[government] can act as an agent of the members of society by helping them to do things they could not otherwise do for themselves." 15 That is, the provision of public goods presents a more direct case in which voluntary agreement - and concomitant gains from such agreement - can be logically inferred, if not directly observed, and thus presents another area in which certain government activities share the simulacra of voluntary exchange. Regardless of the apparent similarities, however, in analyzing the interwar years, all economic activities of government are treated as transfers rather than as katallactics proper.

In cleaving voluntary exchange (as katallactics) and government activities (as transfers), one can still remain cognizant that an exchange-based approach can be used to analyze questions of public choice, or that, on the constitutional level, one can even logically impute voluntary agreement — and perceived gains from such agreement — to the establishment and maintenance of some level of government. ${ }^{16}$ Nevertheless, despite the important basis of agreement in establishing the principles of constitutional constraint, and of the potential for gains from some public goods provisioning, this paper treats all government activities as transfers for four practical reasons. First, this classificatory scheme recognizes that both voluntary actions as well as government mandates can cause resources to move among individuals; though in either case, such movement may not always accord with the full requirements of voluntary exchange spelled out earlier. Second, much of modern government activity constitutes formal transfers, and in many cases-as with income maintenance programs such as Social Security, work relief, and federal unemployment compensationsuch transfer programs can trace their official origins to policy responses initiated during the Great Depression. Third, public goods provision and government-induced resource redistributions share a common root and justification in an externality argument. That is, either the market is said to have "failed" to furnish some mutually beneficial good-such as national defense, for instance-or it has failed to distribute outcomes in accord with some individual's perception of equity. ${ }^{17}$ The purported market failure then rationalizes compulsory adjustment through non-market mediated means (i.e., through government-induced transfers). Fourth and finally, "It is certainly possible, indeed likely, that even a purely protective state would involve some redistribution of income."18 That is, even a minimalist, night-watchman state is likely to entail some degree of wealth transfer. For these reasons, when measuring the extent of the market during the interwar years, government influences on and interactions with the katallaxy will be classified as compulsory transfers rather than as voluntary exchanges. ${ }^{19}$

\section{The Extent of the Market, 1919-1939}

Given that consideration constitutes one half of most exchanges, if one can estimate the total volume of nominal exchange activity, it should be possible to generate a picture of the pattern -if not the precise magnitude-of katallactic activity. ${ }^{20}$ Furthermore, using data from various sources, as documented in the associated Appendix, the total volume of katallactic activity can be further refined into estimates of consumption, production, and 
financial exchange volumes. Armed with the refined estimates, it should then be possible to see how the relative composition of the katallaxy changes over the course of the interwar years.

To develop a first approximation of the extent of the market from 1919 to 1939, the following analysis relies on a measure of bank account clearing activity. ${ }^{21}$ The justification for this approach follows from the observation that in the United States during the interwar years, the consideration element of most exchanges was accomplished principally by cash or check, and that the clearing of such checks relied on the banking system. To be sure, charge accounts existed especially at the merchant level, but the vast network of electronic payments, paperless exchanges, and non-bank intermediaries was still largely in the future. ${ }^{22}$ During the interwar years, even such charge accounts as did exist as well as other debtrelated transactions typically cleared by the transmittal of bank drafts. Of course, bank clearings do not capture every exchange that occurs, only those that contact the commercial banking system. Still, if not in absolute magnitude, the volume of check clearings ought to provide an approximation in pattern of total katallactic volume.

Bank clearings in fact are some of the oldest regularly collected economic statistics in the U.S. The volume of checks and drafts presented at the clearinghouse for collection has been regularly collected since at least the $1850 \mathrm{~s}$, and as might be expected, bank clearings tend to mirror other measures of economic activity closely. ${ }^{23}$ Bank clearings per se', however, suffer from a number of statistical defects, including the fact that they do not include so-called "onus" checks-i.e., checks drawn and cleared within the same institution. Nor do clearings include bank account cash withdrawal activity. In addition, inter-bank checks drawn for purposes of account settlement are included in bank clearings and as such represent an instance of double counting within the clearing statistics themselves. In recognition of the deficiencies in the clearings data the Federal Reserve began collecting a series called "Bank Debits" in 1918.

Bank debits, as the name implies, include all debits to customer deposit accounts. Checks, drafts, and other customer-written transmittals are included, as is cash withdrawal activity at the teller windows, and on-us checks. Inter-bank settlement drafts, however, are excluded. Activity in the U.S. Treasury's Tax and Loan Accounts are also included in bank debits, inasmuch as Federal Reserve branches maintain these accounts to facilitate the banking activities of the U.S. Treasury. Bank debits are thus a more accurate and comprehensive data series as compared to bank clearings, but they lack the longevity of the clearings series.

The Federal Reserve collected bank debits in two distinct categories: outside debits and inside debits. Outside debits are those bank account debits cleared outside New York City. Conversely, inside debits are those occurring within New York City. This distinction enables an interested analyst to isolate the lopsided effects of New York on the statistics given its dominant position as a mercantile, wholesale, and financial center. New York or inside debits in 1929, for instance, were nearly twice as large as the debits from all other clearing cities in the U.S. combined. ${ }^{24}$

Ideally, bank debits would capture every consumption, production, and financial exchange in the economy. In fact, however, bank debits, although superior to bank clearings, are still an imperfect measure of overall exchange activity, and this obtains for several reasons. First, bank debits data were not collected from every financial institution in the 
U.S. because not every institution was a member of the Federal Reserve System. Even here however, some amount of non-member volume would nevertheless be reflected in the data through the correspondent banking relationships non-members customarily maintained with member banks to facilitate check clearing and account settlement. Second, not every exchange transaction was directly intermediated through the banking system. Clearing of stocks through the stock exchange's clearinghouse or by direct presentation of shares to a brokerage firm, for example, need not directly involve the banking system. Third, not all katallactic activity uses money as the medium of exchange. Barter and the direct delivery of commodities to settle a futures contract are two examples of exchanges where money is not directly involved. Finally, not every cash transaction has a corresponding debit in the banking system's books. Money spent from a private hoard, or underground economic exchanges can fall into this category. ${ }^{25}$ In spite of these weaknesses, however, bank debits should provide a reasonable first approximation for determining the pattern if not the precise magnitude of overall exchange activity. Moreover, additional data sources and estimating procedures can be used to augment the debits data, and thereby present a more accurate picture of the katallaxy.

Most consumption-based katallactic activity should be revealed through bank debits. That is, sales of goods and services made by businesses to the final consumer, as well many consumer-to-consumer trades would be reflected directly in bank debit activity. However, some consumption-based economic activity may not directly contact the banking system including household (or autarkic) production, cash-based payments not preceded by a bank account withdrawal, barter, and underground exchange activities. ${ }^{26}$

Perhaps just as important from an exchange perspective, bank debits also reflect exchanges conducted among businesses on behalf of further production, as well as a substantial portion of financial exchanges-i.e., those transactions undertaken to finance production and consumption exchanges that cannot be paid for by the contracting individuals out of their current incomes. That is, most production exchanges (i.e., business-to-business sales revenues as well as payments by businesses for the factors of production) are likely to have had immediate contact with the banking system and, therefore, would be revealed in the bank debits data. Even businesses that, for example, paid workers in cash, would likely first withdraw such cash-paid wages by presentation of a check or other draft drawn on the firm's deposit account. ${ }^{27}$

\section{The Importance of Finance and Speculation}

A potentially significant pitfall with respect to bank debits and its correspondence to overall exchange activity patterns concerns financial transactions. A growing number of financial transactions, especially stock trades, were accomplished during the interwar years without the intermediation of the banking system. Beginning in 1921, for example, New York brokerage firms began clearing trades among themselves through the Stock Clearing Corporation. ${ }^{28}$ From 1921 to 1946, Garvy (1959:19) estimates "the Stock Clearing Corporation replaced payment by check in amounts ranging from less than $\$ 10$ billion to more $\$ 100$ billion a year. If checks for such amounts had been cleared, New York clearings for 1921 to 1946 would have increased on the average by about 12 per cent." ${ }^{, 29}$ In commodities 
trading, moreover, one party to a futures contract has the option of settling the contract at expiration by direct delivery of the underlying commodity rather than through a cash equivalent payment, though such instances tend to be infrequent due to the costs of making such deliveries. ${ }^{30}$ In addition, direct placement of commercial paper through the money markets rather than by rediscounting at banks may also contribute to intermediation without the direct involvement of the banking system. ${ }^{31}$

Given the near-ubiquitous focus of modern macroeconomics on final product, it is not surprising that past studies using the bank debits data have tended to net out the financial impact of New York in order to focus exclusively on consumption-related activities. Evidently, the belief underpinning this line of inquiry is that somehow financial activities such as arranging inventory loans or ensuring liquidity by providing deep markets in corporate securities are at best only indirectly related to size and rate of economic progress, assuming they are related at all. Indeed, a focus on final consumption can lead to no other conclusion, since the effects of all the intermediate stages of production and finance are subsumed in the value of final goods themselves. ${ }^{32}$

Looked at from the perspective of a business ledger, the focus on final consumption and to a lesser degree, on production via net investment - to the exclusion of the financial exchanges that were integral to building a given structure of production-is roughly equivalent to considering only the asset side of a balance sheet. Such a view implicitly ignores or minimizes the importance of the equity side of the ledger. By considering both sides however, who owns what and what those claims are worth, become every bit as important as what is owned and how those assets are employed. ${ }^{33}$ The katallactic approach takes a more inclusive view by considering not only exchange volumes that result from income expenditures related to final consumption, but also by considering exchanges at the intermediate and earlier stages of production, as well as financial and property (i.e., title) exchanges that support the entire process.

A second objection sometimes raised in connection with financial exchanges concerns a variant of the alleged non-productive nature of asset trades, or the dubious nature of financial speculation as such. However, it can be argued that speculation is an indispensable element of a smoothly functioning market.

Trading between men in the same stage of production is speculation. It represents trading to smooth out dynamic changes, to bring about readjustments which would have been unnecessary had conditions really been static, and had the initial plans of enterprisers been adequate. ${ }^{34}$

Some, however, view technological and physical factors as the principal determinants of the volume of production and trade with speculation playing at best a bit part. ${ }^{35}$ Beyond technological and physical factors, however, it is suggested here that trades occurring in connection with title transfers to the means of production, and in connection with speculation more generally are integral components of an advanced division of labor economy, and that such trades can be indicators of a well-functioning price mechanism. Thus, finance and speculation are important components of the katallactic perspective.

In measuring the extent of the market, therefore, the market-based outcomes of the interwar U.S. economy will be classified into consumption katallactics (i.e., exchanges 
undertaken to satisfy final demand), production katallactics (i.e., exchanges undertaken within the structure of production to produce goods and services), and finance katallactics (i.e., exchanges undertaken to finance production or consumption exchanges and to speculate). In addition to summarizing katallactic activity, for a more complete picture of the interwar economy to emerge, non-exchange activities, or voluntary and compulsory transfers, are also considered.

\section{Consumption Katallactics}

Exchanges classified as consumption are those undertaken by individuals to furnish final utility. For example, consumption exchanges include purchases by consumers from businesses or other consumers of final goods and services, such as housing, haircuts, food, clothing, and so on. Kuznets (1946:3-13 and passim) provides an estimate of consumer outlay for the goods and services that provide final utility. ${ }^{36}$ Paraphrasing Kuznets, consumer outlay represents the expenditure of incomes by consumers on goods and services, less any consumer goods used in the production of income such as personal automobiles used in business, for example.

In the Kuznets derivation of consumer outlay, which is based in part on national income, his national income estimates carry an estimate of the net rental incomes received by individuals. ${ }^{37}$ This figure includes rental income generated by the ownership of commercial as well as residential properties. In addition, corporate businesses also receive rental income on properties they lease to consumers or to other firms, but this corporate figure is not included in the national income accounts as it is not the income of individuals. To obtain a more accurate parsing of rental activity between residential and business purposes, total rental incomes within the katallaxy - the sum of both corporate and individual rental incomes-are reclassified as described more fully in the Appendix (Table A.1, columns 3 and 4). The net result apportions total exchanges on behalf of rent between rent paid by individuals for residential properties, and rent paid by businesses for commercial properties.

The national income accounts also include estimates of consumption derived from household production - principally farm products consumed within farm households. ${ }^{38}$ This autarkic production is subtracted from consumer outlay estimates since it does not constitute an exchange per se' (i.e., there is no reciprocal exchange of values with an "other" outside the household). ${ }^{39}$ Therefore, consumer outlay adjusted for autarkic household production and for residential rents becomes the core of the approximation of consumption katallactics presented here.

To apply the bank debits data accurately to this core of consumption katallactics, it is also important to account for the portion of consumption exchanges accomplished through non-bank intermediated currency transactions. To estimate the amount of currency-based ${ }^{40}$ consumption katallactics, it is assumed that publicly held currency turns over outside the banking system at the M1 consumer outlay velocity. ${ }^{41}$ This velocity figure applied to the amount of publicly held currency then yields an estimate of currency-paid consumption katallactics (i.e., consumption exchanges settled using currency that do not directly involve bank intermediation). Therefore, to summarize, the consumer outlay figure adjusted for rent 


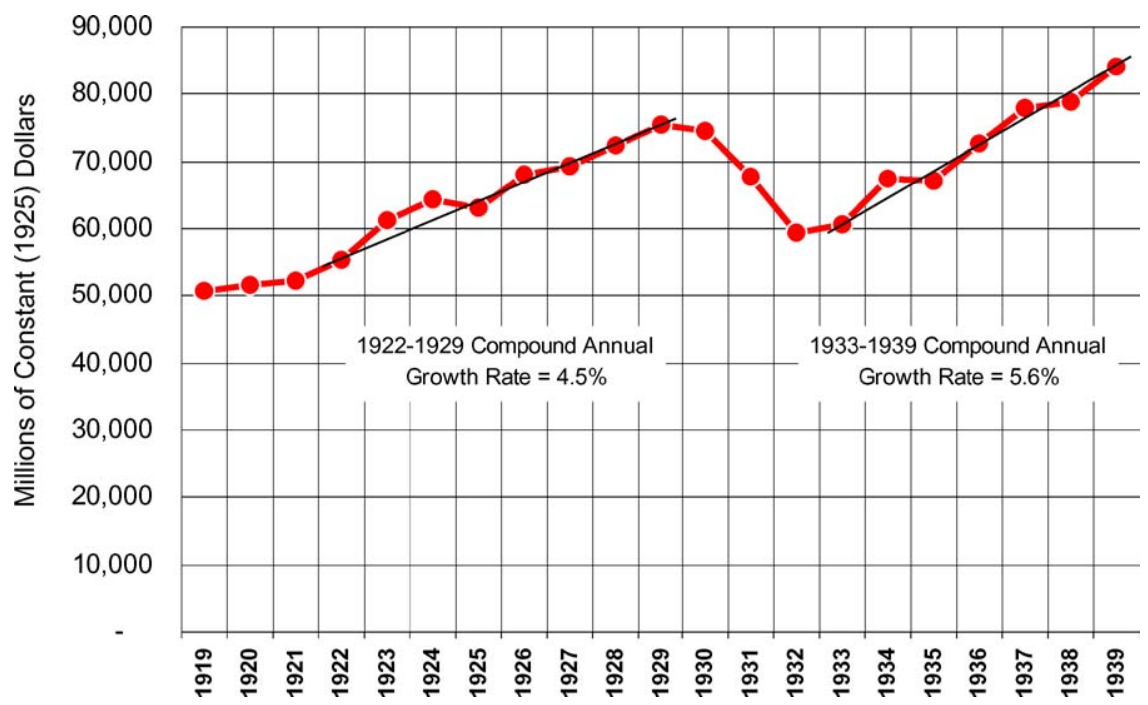

Figure 1. Real consumption katallactics, 1919-1939. Figure 1 traces deflated (or real) estimates of consumptionoriented katallactic activity during the interwar years. It represents consumer exchange volumes undertaken to obtain the goods and services destined for final consumption.

and autarkic consumption, less the estimate of currency-paid consumption katallactics, is then subtracted from the total bank debits. The remainder represents the volume of bank debits used in production, finance, and transfer activities.

Figure 1 summarizes the resulting estimates of consumption katallactics based on the data and adjustments just described. ${ }^{42}$ The estimates in Figure 1 are expressed in constant 1925 dollars to net out price change effects. ${ }^{43}$ Following the 1920-21 post-war depression, from 1922 through 1929, real consumption-based exchange activity grew at a steady compound rate of 4.5 percent per year. The Great Depression is also apparent in the data of Figure 1, as shown by the 19.6 percent overall decline in consumption exchanges between 1929 and 1932. However, it is interesting to note the initially muted response of consumers to the contraction as shown by the comparatively small (1.1 percent) decline in consumption exchanges in 1930 as compared to 1929 . The early attempts by the Hoover administration (and, later, the stronger attempts of the Roosevelt administration) to stimulate consumption-in the mistaken belief that a lack of effective demand, or underconsumption, lay at the heart of the economy's troubles-likely contributed to the initially slow response of consumers to the downturn, and may have protracted the length of the depression itself. Although, as the data for the latter part of the 1930s show, some of the New Deal consumer stimuli apparently had some of their intended effect; inasmuch as consumption-based exchange activity grew at a 5.6 percent compound annual rate from 1933 through 1939, or more than a full percentage point faster than the analogous post-contraction period of the 1920 s (i.e., 1922-1929). 


\section{Production Katallactics}

In the main, businesses engage in two general types of katallactic activity:

(1) Businesses trade with their customers, earning sales revenues in the process.

(2) Businesses also trade for the factors of production such as labor, land, capital, and materials.

To form the foundation from which one may derive the first category of production exchanges, an estimate of total business revenues is required. Accordingly, the estimation procedure, detailed in the Appendix, Table A.2, relies on a standard income statement presentation as an organizing device. The procedure uses estimates of the operating revenues of corporate and entrepreneurial firms obtained from tax return data to provide an approximation of the exchanges occurring between businesses and their customers. The operating revenues of all firms (whether corporate or entrepreneurial) consist of sales to consumers, other businesses, as well as sales to governments. ${ }^{44}$ Embedded within total operating revenues therefore, are sales among businesses for materials, capital equipment, and services. ${ }^{45}$ Materials sales within the structure of production include, for example, sales of iron ore by mining concerns to steel manufacturers, or of flour sales by millers to bakers. With respect to capital equipment, the sale of electric motors or of fabrication equipment, for example, simultaneously constitutes capital goods expenditures by one firm and sales revenues of the capital goods producing firms. ${ }^{46}$ Lastly, revenues earned by the provision of business services may include legal advice, or the purchase of advertising or printing services, for example, by one firm from another. It is possible, therefore, to account for these businessto-business exchanges from either an expenditure or revenue perspective. The estimating procedure used in this paper relies on operating revenue estimates of the goods and services selling firms as derived from the Statistics of Income (SOI) data for both corporate and entrepreneurial firms. ${ }^{47}$

Production revenues include not only sales among firms, but also sales to consumers and to governments. In the consumption katallactics section, sales between businesses and their consumer customers have already been accounted for as consumer outlays for final goods and services, and thus these revenues are subtracted from the estimates of gross operating revenues. An estimate of government purchases of goods and services from businesses is likewise subtracted from gross operating revenues of all businesses in order to classify these government interactions with the katallaxy as transfers rather than exchanges. ${ }^{48}$ In addition, the gross operating revenue figure of all firms also includes the revenues of financial services firms such as banks, brokerages, and insurance companies. These latter revenues are likewise subtracted from the gross operating revenue estimates in order to classify them as finance katallactics.

\section{Certain Factor Payments as Production Katallactics}

Beyond business sales receipts, however, production-related exchanges also include payments of wages and salaries to labor, and business payments of rent to commercial landlords. 
These transactions are treated as production-related exchanges and therefore need to be added to the adjusted operating revenues of production firms-i.e., total operating revenues net of finance-, consumer-, and government-derived revenues-in order to estimate total production katallactics. ${ }^{49}$ Only those wages paid by businesses to employ labor in furtherance of production are included in the estimates of production katallactics. Therefore, wage and salary payments to government employees, to employees of financial services firms, and to labor that provides direct consumer services, such as housekeepers, are netted out. ${ }^{50}$ In addition, transfer payments to labor such as social security, relief, and workers' compensation are likewise deducted and placed in the transfer category. Table A.2, column 13 in the Appendix details the data sources and adjustments made to the data in order to derive the estimates of production-based wage and salary payments just described.

In sum, to determine production-based katallactics, the revenues of financial services firms, consumption katallactics, and government purchases of goods and services are subtracted from the estimate of total operating revenues of corporations and entrepreneurial firms. To this net production revenue figure, one adds estimates of private production wages and business-paid rent, and the result represents an approximation of production katallactics - or exchanges undertaken in furtherance of private production activities. Figure 2 traces the pattern of real production katallactics that results from the estimating procedure just described and as documented in the Appendix, Table A.2. The estimates in Figure 2 are presented in millions of constant 1925 dollars. ${ }^{51}$

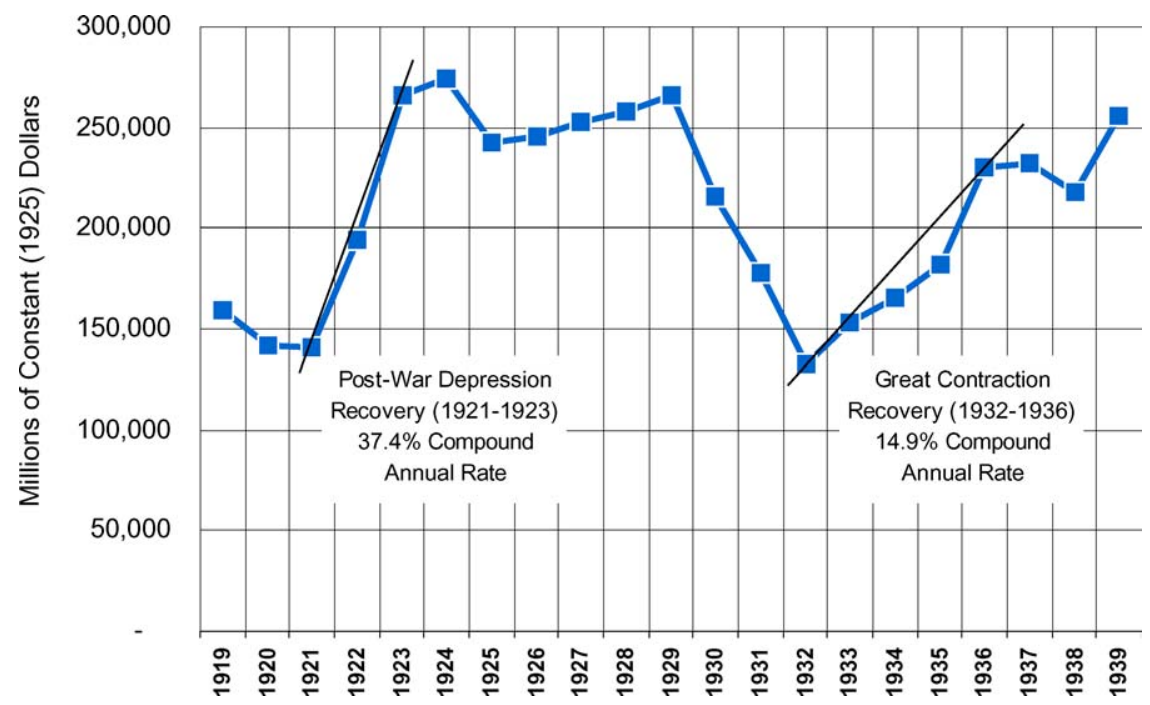

Figure 2. Real production katallactics, 1919-1939. Figure 2 depicts estimates of real production katallactics during the interwar years. It represents the exchange volumes undertaken by firms to obtain labor and land (rent), as well as the revenues derived from business-to-business exchanges for capital goods, materials, and business services. 
The contraction in production attendant with the shift from wartime to a peacetime footing and the effects of the 1920-21 depression are apparent in Figure 2. Once the appropriate adjustments were made, however, a sharp correction lifted real production exchange activity at a compound annual rate of more than 37 percent from 1921 to 1923. Following an eleven and a half percent setback in $1925,{ }^{52}$ real production exchange activity grew steadily for the remainder of the decade at a compound rate of 3.1 percent a year.

With respect to the Great Depression, unlike consumption, the retrenchment in production-related exchanges was sharp and immediate. In 1930, production katallactics fell nearly 19 percent from their 1929 levels. However, in keeping with the underconsumptionist doctrine underpinning government policy at the time, real wages (a component of productive exchanges as described earlier) fell just 0.8 percent in 1930 as compared to 1929. ${ }^{53}$ Apparently, the jawboning of the Hoover administration in favor of maintaining high wages and thereby "purchasing power"—as detailed in Vedder and Gallaway (1993:95, and passim), for example — had some influence on the sluggish adjustment of wages, if only in the short run. ${ }^{54}$ Ultimately, however, the full complement of real production katallactics, including real wages, would fall more than 42 percent from their 1929 levels before reaching their nadir in 1932.

As with consumption katallactics, after 1932, production katallactics began a steady recovery, compounding at an almost 10 percent rate per year through the end of the decade. Interestingly though, the recovery in production exchanges from the Great Contraction was neither as sharp nor as strong as the recovery coming out of the 1920-21 depression. In fact, the average level of 1922-1929 real production exchange activity (of roughly \$250 billion per year) would not be exceeded in the 1930s until 1939. Lastly, the secondary depression of 1937-38 is also apparent in the data of Figure 2, but more will be said about this episode below. ${ }^{55}$

\section{Finance Katallactics}

Put briefly, financial katallactics are determined largely as residuals (i.e., bank debits net of consumption, production, and transfer activities). There are two principal reasons for this approach. First, reliable and complete data on all financial transactions are unavailable. Though much data exist on bank deposits, loan levels, and some securities transactions, some unknown proportion of financial activity remains uncounted. Second, the residual method offers a direct approach to infer at least the pattern of financial exchanges - assuming the other exchange and transfer activities have been accurately taken into account.

To estimate finance katallactics using the bank debits residual method, the total volume of bank debits in each year is decremented by the estimates of bank-intermediated consumption and production katallactics, as well as by the estimated total volume of transfer activities effected through the banking system. ${ }^{56}$ This residual forms the basis of the estimates of finance katallactics. In addition, where reliable estimates of non-bank-intermediated financial exchanges are available, such estimates are added to the residual bank debits figure to 
give a more complete representation of the pattern of financial activity obtaining during the interwar years. In this connection, the clearing activity of the New York Stock Clearing Corporation is perhaps the single largest component of finance activity occurring during the interwar years without banking system intermediation. ${ }^{57}$

Although the volume of stock trades settled through the New York stock clearinghouse was the largest amount of non-bank katallactic activity for which it was possible to account, it seems likely that some volume of trades at the regional exchanges, as well as bond and commodity trades may have been executed too without bank intermediation. Additional research may uncover a means of estimating these volumes, but at present, the residual bank debits figure augmented by the New York stock clearinghouse estimates provides at least an approximation, if perhaps understated, of the pattern of finance katallactics. These nominal volume estimates were then deflated by an index of financial asset prices and those real figures are shown in Figure 3. ${ }^{58}$

With respect to analyzing real financial exchange volumes, it is important to recognize at the outset that increases in the volume of financial exchange activities are not always favorable developments. ${ }^{59}$ Increases in the volume of real financial exchange activity must be considered in conjunction with financial price movements ${ }^{60}$ in order to be accurately interpreted. Doing so gives rise to four general cases for analyzing real financial katallactics $^{61}$ :

(i) Liquidation: Characterized on balance by heavy net selling, or liquidation, of financial assets—-such as loans, stocks, bonds, or other investments-by investors. In the liquidation case, prices fall while real financial transactions volumes rise.

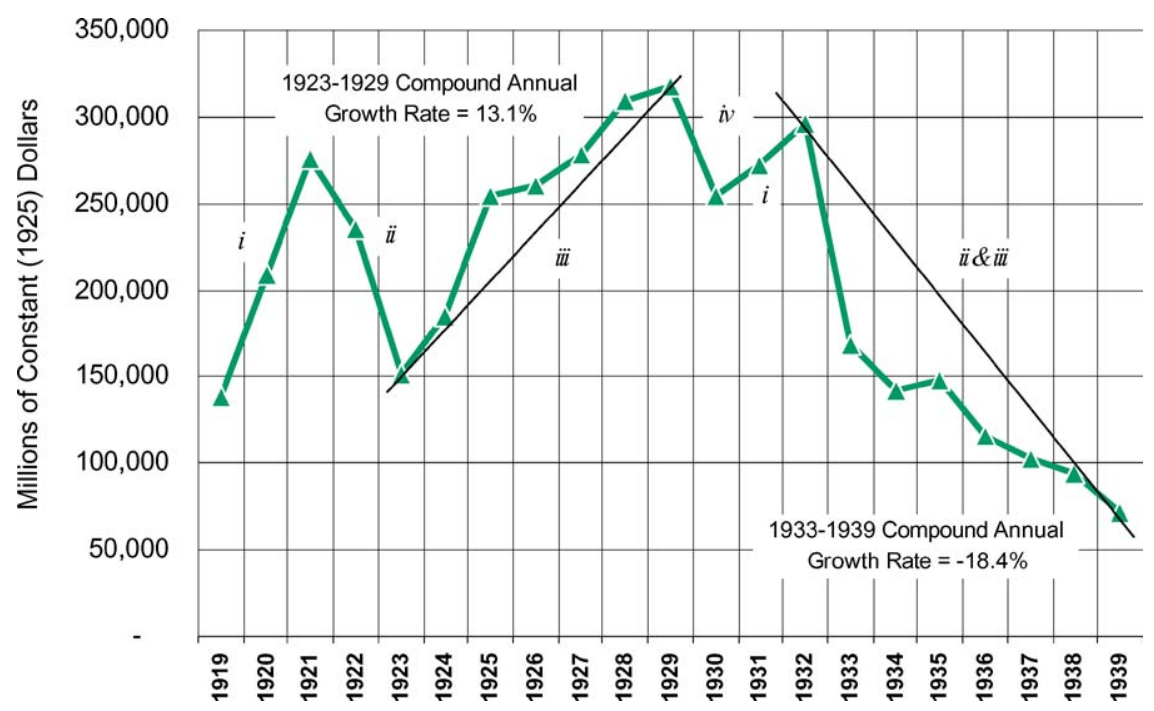

Figure 3. Real finance katallactics, 1919-1939. Figure 3 depicts the volume of real financial exchanges undertaken to finance both consumption and production activities and to engage in speculation. The general cases of price and volume movement appear nearby significant trends in the figure. 
(ii) Consolidation: Characterized on balance by slowing real finance katallactics amid generally rising prices.

(iii) Accumulation: Characterized by the tendency for buyers to prevail on balance. During accumulations, both prices and real finance katallactics rise simultaneously.

(iv) Distribution: Characterized by falling real finance katallactics and falling prices.

The first major rise in real finance katallactics occurs from 1919-1921. This rise coincides with the post war depression and represents a sharp liquidation in financial assets as real volumes rose amid falling prices. Over this three-year period, financial prices fell an average 10 percent per year, while the volume of asset trading activity rose at a compound rate of more than 41 percent per year, implying the net pressure in the financial markets was toward liquidation. After the 1919-1921 liquidation, a consolidation period followed in which real financial katallactics declined, but financial asset prices firmed. This period of consolidation lasted until 1923, after which the 1920s really began to roar amid a great accumulation of financial assets. From 1923 until 1929, real financial katallactic activity rose at a compound annual rate of more than 13 percent, while prices rose even faster, compounding at nearly 18 percent per year.

The initial panic collapse in stock prices in the fall of 1929 gave way to a distribution phase in overall financial asset trading in 1930, as both real trading activity and prices fell roughly 20 percent each as compared to their 1929 levels. ${ }^{62}$ Late in 1930, as it became apparent that recovery was not "just around the corner," generalized financial liquidation follows in the 1931-1932 period, and the liquidation was not just confined to common stocks, but included bonds, bank loans, and eventually bank deposits (as many nervous depositors queued up to withdraw funds-i.e., to liquidate their accounts). Over this two-year period, financial asset prices fell an average 41 percent a year, while real financial katallactics rose 8 percent per year. Although financial asset prices essentially firmed for the remainder of the decade (except for the 1937-1938 depression) rising at a nearly 9 percent compound annual rate, real finance katallactics fell almost continuously over the same period, falling at better than an 18 percent compound annual rate. As early as 1934 in fact, real financial katallactic volumes had fallen below the lowest levels reached at any point in the 1920s and would continue falling steadily from there. In sum, the 1930s were witness to declining real financial exchange activities, punctuated by periodic bouts of significant liquidation in 1931-1932, and again in 1937-1938.

\section{Transfer Activity}

Transfers, as the term is used here, include activities that entail movement of goods and services among individuals and institutions, but that do not qualify under the description of the katallactic process given earlier because at least one element of voluntary exchange is missing. Transfer activities, moreover, are further classified into compulsory and voluntary transfers. Compulsory transfers encompass governmental activities at all levels and include taxation, expenditures, and financing activities, as well as government-mandated 


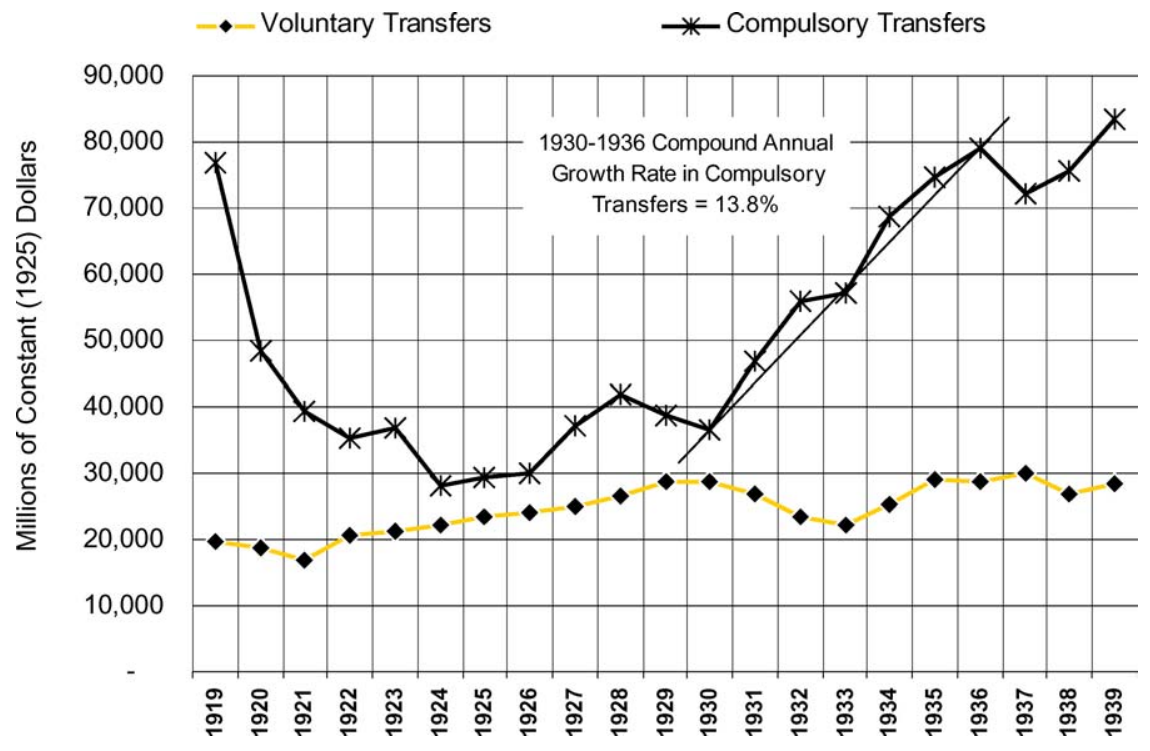

Figure 4. Real transfer activities, 1919-1939. Figure 4 depicts estimates transfers activities; that is, the movements of goods among individuals that do not qualify as voluntary exchanges but are necessary for a fuller appreciation of economic activity during the interwar years.

transfers stemming from income maintenance programs for example. Voluntary transfers, by comparison, include gifts, bequests, and personal-intertemporal transfers of wealth such as dividends, draw, and pensions. ${ }^{63}$ Transfer activities were the most difficult elements to account for and the estimates are necessarily incomplete. ${ }^{64}$ To the extent they could be estimated with reasonable precision, transfers are nevertheless included in this analysis to provide some context for the extent of the market and its relation to non-market intermediated activities. Figure 4 contrasts the estimates of compulsory and voluntary transfers that are estimated to have occurred during the interwar years.

The substantial drop in compulsory transfers following the World War I is largely due to reductions in the financing demands of the federal government following the conclusion of the war. From 1919-1924, compulsory transfer activity fell 63 percent overall, or at an 18 percent compound annual rate. Beyond the post-war reductions in compulsory financial transfers, federal tax reform in the mid-1920s also contributed to lower volume of compulsory transfers during the $1920 \mathrm{~s} .{ }^{65}$ The pattern of real compulsory transfers, however, took a pronounced " $U$ " turn starting around 1930, as the Hoover and then Roosevelt administrations took a more active and permanent role in economic affairs. Compulsory transfers rose with only minor interruptions throughout the 1930s, increasing at a compound annual rate of nearly 14 percent between 1930 and 1936. In fact, by 1936, the compulsory activities of government had surpassed the levels that prevailed in 1919 immediately following the War. Moreover, between 1934-1936, as the Roosevelt New Deal was in full swing, the real volume of compulsory transfers would exceed the volume of real consumption katallactics for the first time since 1919. 
Voluntary transfers by comparison held relatively steady throughout the two decades. This is all the more remarkable given that dividends and draw-the largest components of voluntary transfers - fell in absolute terms through the first third of 1930s, as the profits out of which they are paid also fell. ${ }^{66}$ This suggests that gifts, bequests, and intertemporal transfers among individuals assumed a larger proportionate role in voluntary transfer activities.

\section{The Changing Structure of Production Katallactics}

Consider Figure 5, which summarizes the changing relationship of production katallactics and consumption katallactics, or what might be thought of as a way of applying a katallactic interpretation to the Austrian concept of the structure of production. ${ }^{67}$

As with Figures 1 and 2, the post-war depression is evident in the relative decline in the production-to-consumption ratio. That is, the structure of production contracted relative to consumption, as it underwent a post-war realignment and subsequent depression. Consumption, that is, as shown in Figure 1, stayed relatively flat, thereby leading to a decline in their relative proportions as represented in Figure 5. Then, following the 1920-1921 depression, production recovers and reaches a high of 4.36 times

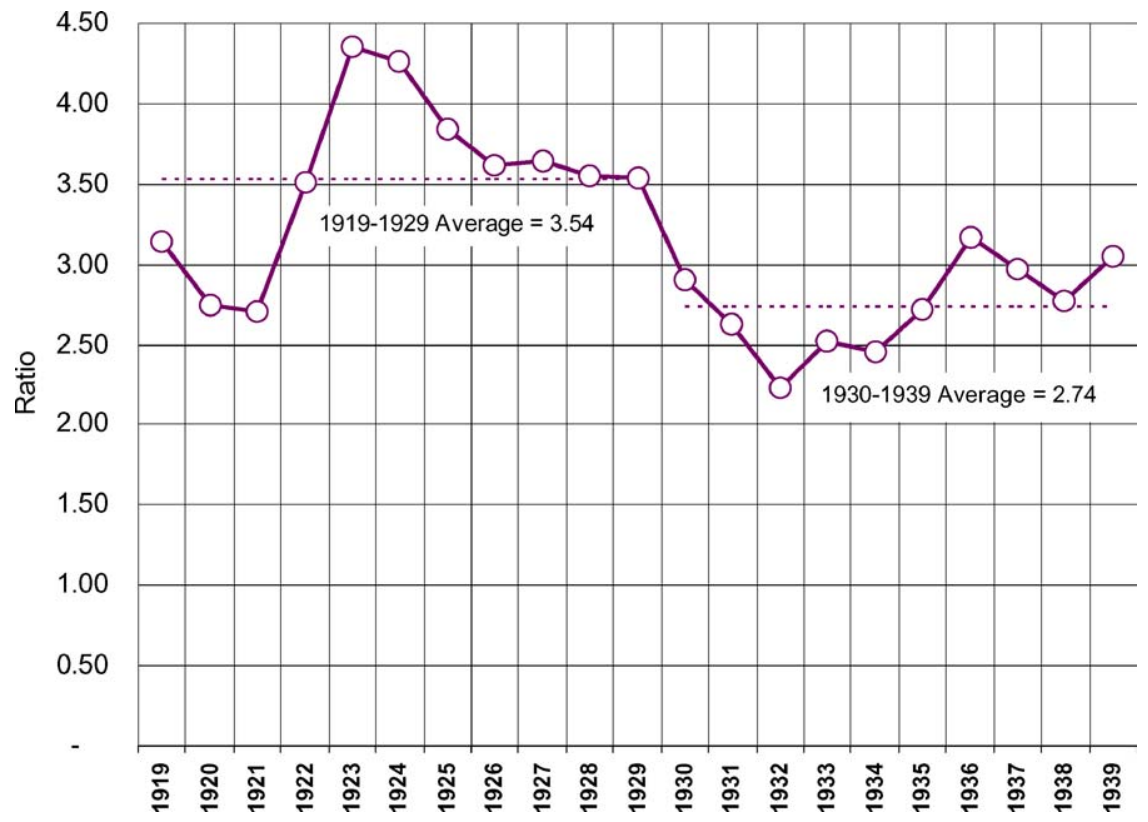

Figure 5. The changing structure of production katallactics. Figure 5 presents the ratio of production katallacticsto-consumption katallactics during the interwar years. As economic policy emphasized consumption in the 1930s, this ratio of production-to-consumption katallactics fell below its 1920 s levels. 
consumption katallactics in 1923, after which it trends down toward its decade average of 3.54. From 1919-1929, in other words, the volume of production exchanges was about three and a half times larger than the volume of exchanges carried out on behalf of final consumption. After the sharp decline in the ratio from 1929-1932, and the comparatively anemic recovery of the 1930s, the production-to-consumption ratio averaged 2.74 from 1930 to 1939 , or about 14 percent lower overall than the prevailing average of the 1920s.

In analyzing Figure 5, it is possible of course, that production never recovers its 1920s relation to consumption owing to malinvestment in the 1920 s that was absent in the $1930 \mathrm{~s} .{ }^{68}$ Certainly, the financial environment was not nearly as stimulative in the 1930s as it had been in the $1920 \mathrm{~s}$ as discussed in connection with Figure $3 .{ }^{69}$ However, the policy responses of the New Deal designed to stimulate consumption should not be overlooked either. Many of the New Deal programs, either deliberately or by unintended consequence, managed to stimulate consumption at the expense of production volumes. The high wage policies aimed at maintaining purchasing power have already been mentioned, but in this connection one must consider too such ill-advised policies as the 1936 undistributed profits tax, as well as sharp increases in the estate and inheritances taxes of 1935 , for example. ${ }^{70}$ Each of these policies, in its own way, lead to a retardation of capital formation as well as to a diminished willingness to invest, but the undistributed profits tax was especially pernicious in this regard. "The proposal was designed, for one thing, to force the distribution of corporate profits by dividends, so that a greatly increased volume of dividends might become subject to income taxes."71

Business savings, of which retained earnings (or undistributed profits) are the key element, constitute the core of capital accumulation, and so it should come as little surprise that a tax on them retarded investment and capital accumulation. Retained earnings are not, as Roosevelt and his advisors evidently thought, idle funds that cause depressions. ${ }^{72}$ Rather, they operate as a cushion for the inevitable shortfalls in income that happen from time to time in any business. Retained earnings also represent a pool of previously generated internal funding that supports, among other things, capital spending. In addition, as Anderson [1979 (1949):374] points out, previously existing credit agreements often required the retention of earnings as a condition for obtaining and keeping a loan. Thus, by diminishing the pool of internally generated capital, the undistributed profits tax meant simultaneously diminished capital investment and credit constriction.

$[F]$ ears that business corporations would reduce their purchase of new equipment out of profits were promptly realized. Case after case of this sort was observed in the latter part of 1936. The measure was eminently successful in diverting corporate profits from the purchase of producers' goods to income for consumers. It was eminently successful in holding down the capital accumulation of the country. ${ }^{73}$

The relatively poorer performance of production as compared to consumption during the 1930s becomes clearer in light of this sampling of policy reactions. Moreover, if it is true that 
production drives consumption and not, as the New Dealers evidently believed, the other way around, then protracted poor economic performance of the 1930s becomes easier to understand too. This is because production katallactics, or exchanges undertaken on behalf of further production, must not only result in the production of goods destined for final consumption, but they must also produce the goods consumed in process of production - such as raw materials, maintenance and repair goods, and so on. In addition, the production exchange process must also result in the production of the means of further production-i.e., it must also produce the capital goods necessary to replace currently existing capital goods as they wear out or become obsolete. ${ }^{74}$ Given the workload that the structure of production is called upon to undertake under normal circumstances, policies that made carrying the productive burden more difficult, while at the same time stimulating consumption, suggest why the ratio of production-to-consumption katallactics shifted relatively in favor of consumption in the 1930s.

\section{Summary and Limitations of Results}

The main concern in this paper has been with the relative volumes of expenditure into the general categories of voluntary exchange and into identifiable categories of transfer activity. Figure 6 presents a consolidated picture of the extent of the market during the interwar

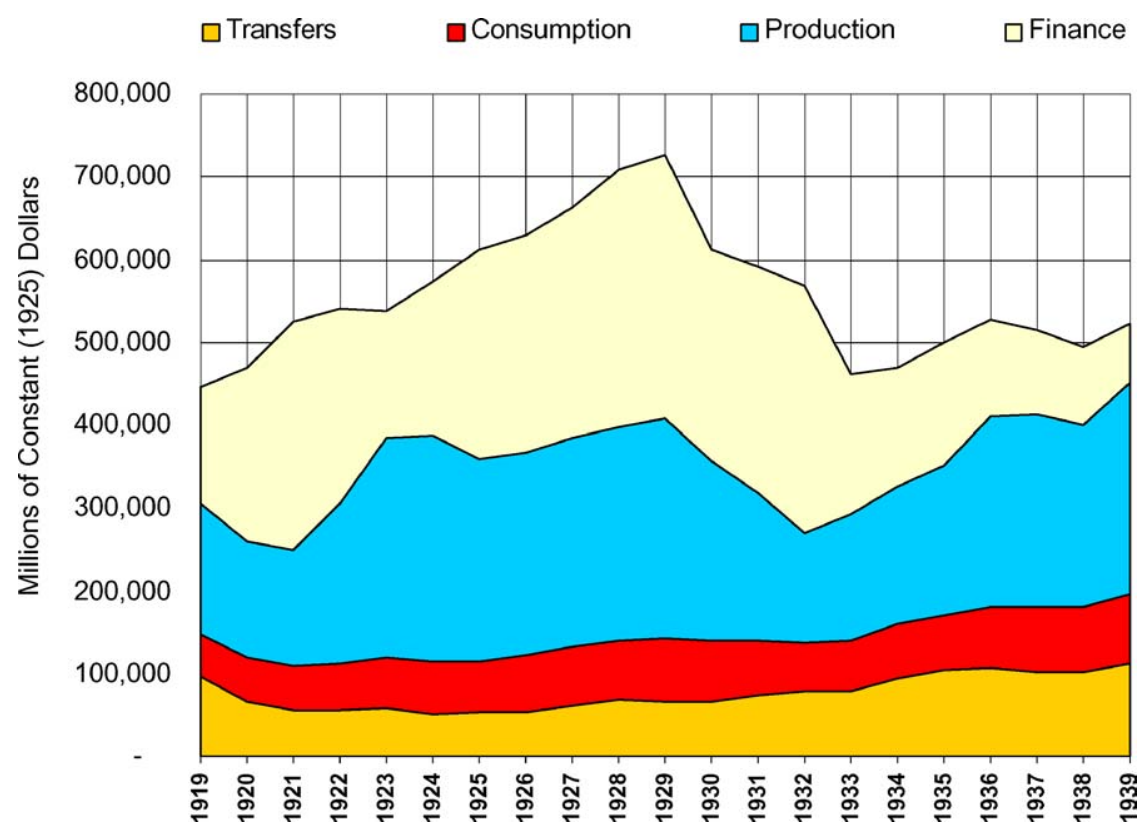

Figure 6. The extent of the market, 1919-1939. Figure 6 summarizes the major categories of katallactic activity (i.e., the extent of the market) and of transfer activities during the interwar years. 
years, including transfer activity occurring alongside the katallaxy. As with the individual categories, the Great Contraction is plainly evident in the aggregate data, and is especially pronounced regarding real finance katallactics. It is as if a giant had put his boot to the entire American economy in the 1930s, and thereby depressed all forms of economic activity but most especially production and finance.

Another interesting feature of Figure 6 is its depiction of consumption exchanges that, while large in their own right - averaging about $\$ 66$ billion per year throughout the interwar period, ${ }^{75}$ in 1925 dollars - are dwarfed by the exchanges on behalf of further production and finance. These findings underscore the idea that the bulk of economic activity (as against the net production of final utility) occurs within the support superstructure of a capitalist economy, rather than in connection with the final consumption stage. Moreover, as was shown above, this capitalistic support superstructure, or katallactic structure of production, was constantly changing in relation to demands placed upon it during the interwar years.

\section{Limitations of Results}

With respect to limitations of these results, attempts to measure the totality of economic outcomes necessarily suffer from a number of limitations inherent in any measurement of overall economic activity as such. First, it is important to realize that the estimates and their classifications, even if perfectly accurate, are not in themselves causal phenomena. At best, they are vote tabulations, or summations of the actions of millions of individual decisions. Second, as Kuznets (1941:xxvi) warned with respect to his national income estimates, "the quantitative definiteness of the estimates makes it easy to forget their dependence upon imperfect data and the consequently wide margins of possible error to which both totals and components are liable." These two facts taken together suggest that it would likely be inapt, therefore, to use these results as independent (or causal) variables in an econometric analysis, for example.

In addition, like the national income estimates, the estimates of katallactic activity are by their natures imprecise. They are subject to analytical choice and measurement error. With respect to the former, the choice of what to include and what to omit (especially as it concerns transfer activities, but also to lesser degree the katallactic categories) was in part a function of the available data. However, the inclusion choice was also a function of the problem as defined at the outset, which can be colored by the preferences of the analyst. With respect to measurement error, the subdivision of katallactic activity relies in part on national income estimates for the interwar years, and thus errors in the national income estimates will be transmitted to the katallactic estimates. As partial remedy to the potential for subjective biases as well as for measurement errors, a detailed Appendix is included that documents the data sources and estimating methodologies used. By including this detail, the hope is that the influence of any errors present can be remedied through subsequent analysis and refinement of measurement techniques in future research. 


\section{Conclusion}

The first principle of katallactic analysis holds that every voluntary exchange relies on agreement. The essence of peaceful cooperation, in other words, is voluntary consent. Katallactics, therefore, implies a contractarian approach to exchange analysis with a direct focus on the requirements of voluntary agreement and thus of exchange. An important finding from the foregoing analysis with respect to the Great Depression and its antecedent exchanges in the 1920 s is that a katallactic approach - as distinguished from a national income and product approach - places as much emphasis on production and finance as it does on income and final demand. Every agreement to exchange comes to the economist's attention, rather than simply the net of those agreements aimed at final demand. This is important because if one does not consider the intermediate stages of production and financing, it becomes more difficult to isolate the possible sources and paths of disturbance in the exchange nexus. In this connection, the highly distilled, final demand focus of national income and product accounting in particular - while valid - provides only a narrow view into the overall market process. Indeed, when compared to even the highly distilled katallactic approach shown here, a consumption-oriented approach makes it appear as if an economist were using just part of his or her faculties to observe economic action. The katallaxy is the extent of the market and therefore those who would analyze market processes and the economic activity that emerges from them might wish to augment their approach with a wider analytical focus.

In sum, the outcomes presented in this paper show that the extent of the market, the katallaxy, contracted substantially during the Great Depression, and that the effects were differentially felt across the three main katallactic categories of consumption, production, and finance. The contraction in finance katallactics, for example persisted almost without interruption throughout the 1930s, while consumption and compulsory transfers recovered steadily. Exchange activity on behalf of further production, however, remained uneven throughout the 1930s. The extent of the interwar years' market, in other words, shrank considerably at the same time its composition changed radically. As Smith's famous observation suggests, therefore, the degree of specialization-i.e., the division of labor and the wealth that results from it—contracted and changed too. Just why the extent of the market contracted initially and then remained in a protracted state of depression is a subject for another paper, but the relative divergences among the katallactic categories suggest where one might wish to begin an investigation.

\section{Appendix}

Data Sources and Derivations of Interwar Katallactic and Transfer Estimates

This Appendix summarizes the data sources and methodologies used to estimate the volume of katallactic and transfer activities in the interwar years. Data are presented in this Appendix in current dollars. Table A.6 summarizes the price indexes used as deflators. 
Estimates of Consumption Katallactics

Table A.1. Consumption Katallactics, 1919-1939.

\begin{tabular}{|c|c|c|c|c|c|c|c|c|}
\hline Year & $\begin{array}{l}\text { Total } \\
\text { bank } \\
\text { debits } \\
(1)\end{array}$ & $\begin{array}{l}\text { Consumer } \\
\text { outlay } \\
\text { (2) }\end{array}$ & $\begin{array}{c}\text { Rental } \\
\text { income of } \\
\text { individuals } \\
\text { (3) }\end{array}$ & $\begin{array}{l}\text { Consumer- } \\
\text { paid rents } \\
\text { (4) }\end{array}$ & $\begin{array}{c}\text { Autarkic } \\
\text { household } \\
\text { production } \\
\text { (5) }\end{array}$ & $\begin{array}{c}\text { Total } \\
\text { consumption } \\
\text { katallactics } \\
\text { (6) }\end{array}$ & $\begin{array}{c}\text { Currency-paid } \\
\text { consumption } \\
\text { (7) }\end{array}$ & $\begin{array}{l}\text { Consumption } \\
\text { settled via } \\
\text { bank debits } \\
\text { (8) }\end{array}$ \\
\hline 1919 & 455,300 & 53,988 & 3,966 & 2,665 & 2,556 & 50,131 & 9,953 & 40,177 \\
\hline 1920 & 483,000 & 63,011 & 4,287 & 2,861 & 2,509 & 59,076 & 11,963 & 47,113 \\
\hline 1921 & 398,800 & 56,263 & 4,470 & 2,982 & 1,746 & 53,029 & 10,677 & 42,352 \\
\hline 1922 & 439,300 & 56,205 & 4,896 & 3,241 & 1,717 & 52,833 & 9,552 & 43,281 \\
\hline 1923 & 463,800 & 62,887 & 5,165 & 3,447 & 1,772 & 59,397 & 10,879 & 48,518 \\
\hline 1924 & 491,600 & 66,181 & 5,631 & 3,773 & 1,706 & 62,617 & 11,067 & 51,550 \\
\hline 1925 & 570,100 & 66,588 & 5,465 & 3,734 & 1,827 & 63,030 & 10,268 & 52,762 \\
\hline 1926 & 608,000 & 72,110 & 5,141 & 3,597 & 1,875 & 68,691 & 11,071 & 57,620 \\
\hline 1927 & 673,800 & 71,806 & 5,078 & 3,614 & 1,725 & 68,617 & 10,977 & 52,639 \\
\hline 1928 & 806,400 & 73,938 & 4,941 & 3,583 & 1,724 & 70,856 & 10,919 & 59,937 \\
\hline 1929 & 935,000 & 76,723 & 4,917 & 3,530 & 1,713 & 73,623 & 11,217 & 62,406 \\
\hline 1930 & 661,800 & 73,514 & 4,265 & 3,275 & 1,552 & 70,972 & 10,691 & 60,281 \\
\hline 1931 & 481,200 & 60,254 & 3,026 & 2,574 & 1,265 & 58,537 & 10,508 & 48,029 \\
\hline 1932 & 322,400 & 47,282 & 2,090 & 1,969 & 993 & 46,168 & 11,163 & 35,005 \\
\hline 1933 & 282,800 & 45,886 & 2,114 & 1,854 & 1,030 & 44,596 & 11,855 & 32,741 \\
\hline 1934 & 331,500 & 52,777 & 1,905 & 1,729 & 1,125 & 51,476 & 11,242 & 40,234 \\
\hline 1935 & 374,300 & 53,963 & 2,143 & 1,886 & 1,320 & 52,386 & 10,037 & 42,349 \\
\hline 1936 & 428,600 & 59,206 & 2,186 & 1,855 & 1,394 & 57,481 & 10,504 & 46,978 \\
\hline 1937 & 433,000 & 65,874 & 2,579 & 2,079 & 1,434 & 63,940 & 12,032 & 51,908 \\
\hline 1938 & 373,500 & 64,876 & 2,575 & 2,303 & 1,235 & 63,369 & 11,854 & 51,516 \\
\hline 1939 & 389,700 & 67,900 & 2,577 & 2,494 & 1,209 & 66,607 & 12,080 & 54,527 \\
\hline
\end{tabular}

Notes

(1) Taken from NBER Macrohistory Database, series M12030, "Bank Debits." The data are for the 141 banking centers across the U.S. and include New York City (i.e., the data include both "inside" and "outside" debits). The original source for the NBER data is Federal Reserve Board (1943).

(2) Taken from NBER series A06073, "Total Consumer Outlay in Current Prices.” Original source for NBER data, Kuznets (1946, Table I-5:35).

(3) Taken from NBER series A08184, "Net Rent Received by Individuals." The original source for the NBER data is Kuznets (1941, Table 57:322-323). The missing 1939 data point was calculated according the average percentage share of rent in national income (excluding rental income of individuals) prevailing over the period 1933 to 1938 , or approximately 4.1 percent. The national income figure, less rent, was calculated as the sum of wages and salaries (NBER series A08181), entrepreneurial draw (NBER series A08183), dividends (NBER series A08185), and interest income (NBER series A08186). The original NBER data source for the national income components was Kuznets (1941, Tables 62, 65, 57, and 57 respectively).

(Continued on next page.) 
Table A.1. (Continued).

(4) Represents the rent paid by individuals for the use of non-production real estate. It is based on an estimated figure for total rental incomes-i.e., rents received by individuals combined with rental incomes of corporations. Corporate rental incomes were reported in detail on the SOI from 1929 through 1939. To estimate the missing corporate rental incomes from 1919 to 1928, the known values of corporate rental incomes (1929 to 1939) were regressed against rents received by individuals for the same years. The resulting coefficients were then used to estimate rental incomes of corporations for the missing years. The equation estimate is: RIC $=1109.66+0.298$ (RII); where, RIC is the rental income of corporations, RII is the rental incomes received by individuals.

Then, to estimate the consumer-paid portion of rents, the total rental income figure (individuals' rental income plus corporate rental income) is allocated according to the relative stocks of residential and commercial land and structures, as appear in Historical Statistics of the United States [HSUS], (1976, vol. 1, Tables F449, 450, and F451 for structures, and Tables F464, F465, F466, and F467 for land: 256). Data on the real estate stock of the United States were available for 1912, 1922, 1929, 1933, and 1939. Straight-line interpolations on the stock of land and structures generated estimates for the missing years' data.

(5) Autarkic household production is taken from the HSUS (1976, vol. 1, Table K269: 483). It represents the value of the farm products consumed within farm households.

(6) Total Consumption Katallactics $=(2)-(3)+(4)-(5)$.

(7) Cash-paid consumption represents the portion of katallactic consumption paid for with currency as against payment by check or other draft that would be revealed directly in the bank debits data. It is subtracted from the estimate of consumption katallactics (6) to determine the volume of consumption exchanges settled through banking system intermediation. The volume of currency-paid consumption exchanges is estimated by applying the consumer outlay velocity of M1 to the volume of publicly held currency (i.e., Federal Reserve notes, gold, and minor coin). Data sources are as described in the main body of the text, in the "Consumption Katallactics" section.

(8) Consumption Settled via Bank Debits $=(6)-(7)$.

\section{Estimates of Production Katallactics}

Table A.2. Production katallactics, 1919-1939.

\begin{tabular}{cccccccc}
\hline & $\begin{array}{c}\text { Gross } \\
\text { operating } \\
\text { revenues } \\
\text { Year }\end{array}$ & $\begin{array}{c}\text { Financial } \\
\text { firm } \\
\text { revenues } \\
(10)\end{array}$ & $\begin{array}{c}\text { Consumption } \\
\text { katallactics } \\
(11)\end{array}$ & $\begin{array}{c}\text { Government } \\
\text { purchases of } \\
\text { goods \& services } \\
(12)\end{array}$ & $\begin{array}{c}\text { Production } \\
\text { wages \& } \\
\text { salaries } \\
(13)\end{array}$ & $\begin{array}{c}\text { Business- } \\
\text { paid rents } \\
(14)\end{array}$ & $\begin{array}{c}\text { Total } \\
\text { production } \\
\text { katallactics } \\
(15)\end{array}$ \\
\hline 1919 & 257,501 & 11,459 & 50,131 & 16,952 & 31,352 & 3,235 & 213,547 \\
1920 & 252,284 & 16,906 & 59,076 & 6,597 & 38,620 & 3,434 & 211,759 \\
1921 & 173,766 & 14,783 & 53,029 & 6,353 & 29,992 & 3,539 & 133,132 \\
1922 & 218,052 & 13,292 & 52,833 & 5,553 & 31,428 & 3,803 & 181,606 \\
1923 & 295,861 & 13,335 & 59,397 & 5,328 & 37,455 & 3,932 & 259,187 \\
1924 & 300,885 & 14,606 & 62,617 & 5,738 & 37,137 & 4,183 & 259,245 \\
1925 & 287,249 & 18,319 & 63,030 & 6,003 & 38,473 & 4,024 & 242,394 \\
1926 & 286,954 & 18,656 & 68,691 & 6,058 & 40,898 & 3,769 & 238,215 \\
1927 & 283,888 & 19,802 & 68,617 & 6,318 & 40,910 & 3,681 & 233,742 \\
1928 & 300,116 & 26,633 & 70,856 & 6,776 & 41,649 & 3,548 & 241,050 \\
1929 & 302,118 & 23,810 & 73,623 & 7,045 & 44,146 & 3,399 & 245,185 \\
\hline
\end{tabular}


Table A.2. (Continued).

\begin{tabular}{cccccccc}
\hline & $\begin{array}{c}\text { Gross } \\
\text { operating } \\
\text { revenues } \\
(9)\end{array}$ & $\begin{array}{c}\text { Financial } \\
\text { firm } \\
\text { revenues } \\
(10)\end{array}$ & $\begin{array}{c}\text { Consumption } \\
\text { katallactics } \\
(11)\end{array}$ & $\begin{array}{c}\text { Government } \\
\text { purchases of } \\
\text { goods \& services } \\
(12)\end{array}$ & $\begin{array}{c}\text { Production } \\
\text { wages \& } \\
\text { salaries } \\
(13)\end{array}$ & $\begin{array}{c}\text { Business- } \\
\text { paid rents } \\
(14)\end{array}$ & $\begin{array}{c}\text { Total } \\
\text { production } \\
\text { katallactics }\end{array}$ \\
\hline 1930 & 235,994 & 20,604 & 70,972 & 6,692 & 39,704 & 3,123 & 180,554 \\
1931 & 174,823 & 17,970 & 58,537 & 7,665 & 32,529 & 2,432 & 125,612 \\
1932 & 125,225 & 13,974 & 46,168 & 7,996 & 24,178 & 1,842 & 83,109 \\
1933 & 136,160 & 12,365 & 44,596 & 5,922 & 22,396 & 1,719 & 97,391 \\
1934 & 163,611 & 12,777 & 51,476 & 7,212 & 26,174 & 1,585 & 119,906 \\
1935 & 184,137 & 13,074 & 52,386 & 8,198 & 28,538 & 1,710 & 140,727 \\
1936 & 225,630 & 13,072 & 57,481 & 8,926 & 32,105 & 1,663 & 179,919 \\
1937 & 241,450 & 13,575 & 63,940 & 8,093 & 35,914 & 1,844 & 193,599 \\
1938 & 212,377 & 9,870 & 63,369 & 7,441 & 32,241 & 2,019 & 165,957 \\
1939 & 240,425 & 11,224 & 66,607 & 8,771 & 34,929 & 2,162 & 190,913 \\
\hline
\end{tabular}

Notes

(9) The sum of revenues of corporations reporting net incomes and net deficits to the Bureau of Internal Revenue (as reported in the Statistics of Income, and summarized in the Statistical Abstract of the United States [SAUS], various editions 1922 to 1943), plus the revenue estimates of entrepreneurial firms-sole proprietor and partnership - derived from reported net incomes on individual income tax returns (as reported in the Statistics of Income, summarized in the SAUS, various editions 1922 to 1943). Entrepreneurial revenues are estimated by grossing up their reported net incomes according to the long-run gross margins prevailing for U.S. corporations from 1919 to 1939 under the assumption that competition causes profit rates to tend towards equality. Baumol (1959) offers a different interpretation.

(10) Financial firm revenues are calculated analogously to those for all firms as described in column 9; however, rental incomes of financial firms are first deducted. Data on rental incomes of corporate financial firms is unavailable from 1919 to 1928 , but are assumed to constitute approximately 10 percent of total financial firms' revenues, which is slightly more than the $9.6 \%$ rate that prevailed in 1929. Entrepreneurial financial firms' revenues were grossed up according to the average operating margins of corporate financial services firms (or 11 percent) prevailing between 1919 and 1939. The net income figure on which the entrepreneurial gross up is based was derived by applying the ratio of private production income obtained in financial services to total private income from all sources, as appears in Martin (1939, Table 16: 58-59) to Other Entrepreneurial Income, as appears in Martin (1939, Table 14: 44-45). The years 1938 and 1939 for entrepreneurial financial services firms were derived by applying the average ratio of entrepreneurial-to-corporate operating incomes for 1935-1937 (or 30.8 percent) to the operating incomes of corporate financial services firms for the years 1938 and 1939 as taken from the corporate data in the Statistics of Income.

(11) Table A.1, column 6.

(12) Government expenditures on goods and services are estimated by subtracting from total government expenditures at all levels of government (as described below in Table A.5, column 29), government wage and salary payments to government employees, and government-induced transfers to individuals (such as workers' compensation, social security payments, etc.). Government employees' wage and salary payments are taken from Martin (1939, Table 41: 90) for the years 1919-1937. The years 1938 and 1939 are estimated by multiplying the number of full-time federal government employees (as found in HSUS vol. 2, Table Y308:1102) by the average annual earnings of full-time federal government employees (as found in HSUS vol. 1, Table D764: 167), and by similar calculation for state and local government employees using HSUS 
Table A.2. (Continued).

(1976, vol. 2, Table Y332: 1104, and vol. 1, D762: 167, respectively). Government-induced transfers to individuals are calculated as described in Table A.5, column 31.

(13) Private wages and salaries exclude transfer payments to individuals and wage and salary payments to government employees. Therefore, from the Kuznets figure for total wage and salary payments exclusive of transfer payments (i.e., NBER series A08181 "Wages and Salaries Payments, Total," original source Kuznets [1941, Table 62: 332-333]), subtract the estimates for wage and salary payments to government employees, estimated as described above in column 12. The remainder is an estimate of total private wage and salary payments. To obtain private production wages and salaries payments, subtract wages and salaries paid to employees of financial services firms (as these will be accounted for under the financial katallactics estimates). Martin (1939, Table 7: 28-29) provides estimates of wages and salaries paid by financial services firms through 1937. Estimates for 1938 and 1939 are based on extrapolations of a fitted trend line to Martin's observations of financial services wages and salaries obtaining from 1933 through 1937 . The estimated trend line is given by, FWSP $=1604.5+101.7(\mathrm{t})$, where FWSP equals the financial services firms' wage and salary payments, and $(\mathrm{t})$ is the trend variable. (The dramatic change in the relative importance of financial katallactics and consequently in employment by financial firms in the 1930s is the rationale for basing the extrapolation only on observations following the Great Contraction.) Transfer payments to financial services firms' employees are subtracted from the wage and salary payments to those employees by applying the ratio of wages and salaries of financial firms (inclusive of transfer payments) to total wages and salaries (inclusive of transfers, or NBER series A08181a) to the difference between NBER A08181a and A08181. The difference between NBER series A08181a ("Wages, Salaries, and Other Payments to Employees," original source, Kuznets [1941, Table 57: 322-323]) and A08181 ("Wages and Salaries Payments, Total," original source Kuznets [1941, Table 62: 332-333]) yields an estimate of total transfer payments to individuals (labor) such as social security, workers' compensation, insurance, and private pension payments.

(14) Business-paid rents are the remainder of total rental income after subtracting consumer-paid rents. The derivation of these latter two estimates is described under Table A.1, column 4.

(15) Total Production Katallactics $=(9)-(10)-(11)-(12)+(13)+(14)$.

\section{Estimates of Finance Katallactics}

Table A.3. Finance katallactics, 1919-1939.

\begin{tabular}{|c|c|c|c|}
\hline Year & $\begin{array}{l}\text { Residual bank } \\
\text { debits } \\
\text { (16) }\end{array}$ & $\begin{array}{c}\text { Stock clearinghouse } \\
\text { transactions } \\
(17)\end{array}$ & $\begin{array}{c}\text { Finance } \\
\text { katallactics } \\
\quad(18)\end{array}$ \\
\hline 1919 & 110,391 & - & 110,391 \\
\hline 1920 & 151,214 & - & 151,214 \\
\hline 1921 & 168,962 & 8,947 & 177,909 \\
\hline 1922 & 165,944 & 16,263 & 182,207 \\
\hline 1923 & 103,981 & 15,238 & 119,219 \\
\hline 1924 & 136,200 & 17,369 & 153,569 \\
\hline 1925 & 227,323 & 26,957 & 254,280 \\
\hline 1926 & 263,003 & 25,980 & 288,982 \\
\hline 1927 & 325,911 & 37,744 & 363,655 \\
\hline 1928 & 443,741 & 67,468 & 511,208 \\
\hline
\end{tabular}


Table A.3. (Continued).

\begin{tabular}{|c|c|c|c|}
\hline Year & $\begin{array}{l}\text { Residual bank } \\
\text { debits } \\
\text { (16) }\end{array}$ & $\begin{array}{c}\text { Stock clearinghouse } \\
\text { transactions } \\
(17)\end{array}$ & $\begin{array}{c}\text { Finance } \\
\text { katallactics } \\
\quad(18)\end{array}$ \\
\hline 1929 & 567,144 & 100,361 & 667,505 \\
\hline 1930 & 364,634 & 56,252 & 420,886 \\
\hline 1931 & 249,040 & 35,496 & 284,536 \\
\hline 1932 & 146,571 & 20,979 & 167,549 \\
\hline 1933 & 97,457 & 24,982 & 122,439 \\
\hline 1934 & 103,862 & 15,750 & 119,613 \\
\hline 1935 & 115,860 & 18,705 & 134,565 \\
\hline 1936 & 120,548 & 24,407 & 144,955 \\
\hline 1937 & 108,482 & 19,717 & 128,199 \\
\hline 1938 & 78,424 & 12,403 & 90,827 \\
\hline 1939 & 59,725 & 13,853 & 73,579 \\
\hline
\end{tabular}

Notes

(16) This column reflects bank debits (Table A.1, column 1) remaining after subtracting bank-intermediated consumption katallactics (Table A.1, column 8), bank-intermediated voluntary and compulsory transfer activities (Table A.5, column 33), and production katallactics (Table A.2, column 15).

(17) Stock clearinghouse transactions reflect those stock trades settled without the direct intermediation of the banking system-i.e., stock trades cleared through the Stock Clearing Corporation in New York, which began operations in 1921, see Garvy (1959:21). Machlup (1940:376-381) provides monthly data on the clearinghouse's operations of the New York Stock Exchange (NYSE) and on the total NYSE volume of trading activity from March 1929 through December 1938, as well as annual percentages of check obviation effected by the NYSE clearing operation from 1925 through 1938. From these as well as NBER data, it is possible to estimate the volume of stock trades settled through the clearinghouse for the years 1921 through 1928 and for 1939

First, to estimate the total volume of NYSE trades occurring in the years 1921 through 1928, NBER monthly series M11003, "Stocks, Value of Shares Sold on the New York Stock Exchange," from 1915 to 1920 was regressed against monthly share volumes and stock prices data (NBER series M11002, "Stocks, Number of Shares Sold on the New York Stock Exchange," and M11025, "Index of All Common Stock Prices, Cowles Commission and Standard \& Poors Corporation" respectively) for the same time period using a first order autoregressive process, and omitting an intercept term. (NBER series M11003 stops after December 1920, and this is the reason for estimating the first equation using monthly data from 1915 to 1920.) The estimated equation in nominal form is given by TDV $=\operatorname{Vol}^{\alpha} \mathrm{P}^{\beta}$. Using natural $\log$ s the nominal equation is transformed into: $\ln \left(\mathrm{TDV}_{t}\right)=\alpha \ln \left(\mathrm{Vol}_{t}\right)+\beta \ln \left(\mathrm{P}_{t}\right)$, where $\mathrm{TDV}_{t}$ is NBER series M11003 for period " $\mathrm{t}$ ", $\mathrm{Vol}_{t}$ is NBER series M11002 for period " $\mathrm{t}$ ", $\mathrm{P}_{t}$ is NBER series M11025 for period " $\mathrm{t}$ ". The equation estimate is: $\ln \left(\mathrm{TDV}_{t}\right)=0.96713\left[\ln \left(\mathrm{Vol}_{t}\right)\right]+1.0462\left[\ln \left(\mathrm{P}_{t}\right)\right]$, with a first order autocorrelation coefficient $=$ 0.9717. This equation was then used to forecast the total dollar value of NYSE shares sold between January 1921 and July 1924, using the known observations from M11002 and M11025 as independent variables.

To estimate the total dollar volume of stock trades occurring from August 1925 to February 1929, a first order autoregressive procedure was again used in which Machlup's reported total dollar value of all contracts traded on the NYSE (1940, Table XIV: 377-381) from March 1929 through December 1938 was regressed against the NBER price and volume data as previously given. The resulting coefficients were then used to forecast backwards to obtain estimates for August 1925 through February 1929. The resulting equation estimate is given as: $\ln \left(\mathrm{TDV}_{t}\right)=0.60154\left[\ln \left(\mathrm{Vol}_{t}\right)\right]+1.2192\left[\ln \left(\mathrm{P}_{t}\right)\right]$, where $\ln \left(\mathrm{TDV}_{t}\right)$ is Machlup's data on total value of all NYSE stocks traded, $\ln \left(\mathrm{Vol}_{t}\right)$ is NBER series M11002, $\ln \left(\mathrm{P}_{t}\right)$ is NBER series M11025, with 
Table A.3. (Continued).

a first order autocorrelation coefficient $=0.90246$. The overlapping forecasts from both equation estimates (i.e., using NBER M11003 and Machlup's data) were averaged to derive forecasts of total dollar value of shares traded between August 1924 and July 1925. The equation estimate derived from Machlup's data was also used to estimate the total dollar value of NYSE trades for 1939.

A noticeable structural change in the data of stock exchange volumes and prices beginning around 1925 is one reason for using Machlup's data to forecast backwards, rather than using the NBER data from 1915 to 1920 to forecast beyond 1925. In addition, evidence cited in Anderson (1949 [1979]:119-147) suggests that three major Federal Reserve discounting and open market operations beginning in 1922 occurring again in 1924 and again in 1927 may have contributed to a boom in securities' prices. Lastly, 1925 is the approximate midpoint between the end of NBER M11003 in December 1920, and the beginning of Machlup's dollar volume data in March 1929.

Finally, to estimate the dollar value of stock trades settled via the clearinghouse for 1921 through 1924 and for 1939, an average check obviation rate of 79.3 percent was applied against the estimates just described. This figure represents the average obviation rate from 1925 to 1938 as reported in Machlup (1940, Table XIII:376). To estimate the percentage of trades cleared without checks for 1925 through 1938, Machlup's reported obviation rates were applied to the estimates derived as just described for 1925 to 1928 , and to the actual observations of total dollar value of stock trades from 1929 to 1938 . The estimates presented in column 17 are within those discussed in Garvy (1959:19), where he suggests the Clearing Corporation's activities replaced payment by check in amounts ranging from less than $\$ 10$ billion per year to more than $\$ 100$ billion per year between 1921 and 1946.

(18) Finance Katallactics $=(16)+(17)$

\section{Estimates of Voluntary Transfer Activities}

Table A.4. Voluntary transfers, 1919-1939.

\begin{tabular}{|c|c|c|c|c|c|c|c|c|c|}
\hline Year & $\begin{array}{c}\text { Dividends } \\
\text { (19) }\end{array}$ & $\begin{array}{c}\text { Entrepreneurial } \\
\text { draw } \\
(20)\end{array}$ & $\begin{array}{c}\text { Voluntary } \\
\text { transfers } \\
\text { to labor } \\
\text { (Pensions, etc.) } \\
\text { (21) }\end{array}$ & $\begin{array}{l}\text { Contributions } \\
\& \text { gifts } \\
\text { (22) }\end{array}$ & $\begin{array}{l}\text { Non-monetary } \\
\text { gifts } \\
(23)\end{array}$ & $\begin{array}{c}\text { Bequests } \\
\text { (24) }\end{array}$ & $\begin{array}{c}\text { Autarkic } \\
\text { production } \\
(25)\end{array}$ & $\begin{array}{l}\text { Voluntary } \\
\text { transfers } \\
\text { (26) }\end{array}$ & $\begin{array}{c}\text { Voluntary } \\
\text { transfers } \\
\text { settled via } \\
\text { bank debits } \\
\text { (27) }\end{array}$ \\
\hline 1919 & 3,222 & 11,782 & 85 & 322 & - & 1,386 & 2,556 & 19,353 & 15,411 \\
\hline 1920 & 3,589 & 13,477 & 143 & 369 & - & 1,386 & 2,509 & 21,474 & 17,579 \\
\hline 1921 & 3,308 & 10,269 & 137 & 469 & - & 1,386 & 1,746 & 17,315 & 14,183 \\
\hline 1922 & 3,437 & 10,789 & 139 & 442 & - & 3,130 & 1,717 & 19,653 & 14,807 \\
\hline 1923 & 4,169 & 11,345 & 140 & 535 & - & 2,804 & 1,772 & 20,766 & 16,189 \\
\hline 1924 & 4,339 & 11,946 & 155 & 611 & 271 & 2,567 & 1,706 & 21,594 & 17,050 \\
\hline 1925 & 5,189 & 12,503 & 155 & 475 & 154 & 3,001 & 1,827 & 23,305 & 18,322 \\
\hline 1926 & 5,945 & 12,452 & 164 & 484 & - & 3,408 & 1,875 & 24,328 & 19,046 \\
\hline 1927 & 6,424 & 12,621 & 166 & 508 & - & 3,173 & 1,725 & 24,617 & 19,719 \\
\hline 1928 & 7,074 & 12,876 & 171 & 533 & - & 3,554 & 1,724 & 25,932 & 20,654 \\
\hline 1929 & 8,356 & 13,385 & 177 & 529 & - & 3,893 & 1,713 & 28,053 & 22,447 \\
\hline 1930 & 8,202 & 12,774 & 205 & 425 & - & 4,166 & 1,552 & 27,324 & 21,607 \\
\hline 1931 & 6,151 & 11,208 & 289 & 328 & - & 4,076 & 1,265 & 23,316 & 17,976 \\
\hline 1932 & 3,886 & 9,747 & 332 & 335 & 51 & 2,830 & 993 & 18,174 & 14,300 \\
\hline 1933 & 3,127 & 9,019 & 706 & 282 & 184 & 2,061 & 1,030 & 16,409 & 13,134 \\
\hline
\end{tabular}


Table A.4. (Continued).

\begin{tabular}{|c|c|c|c|c|c|c|c|c|c|}
\hline Year & $\begin{array}{l}\text { Dividends } \\
\text { (19) }\end{array}$ & $\begin{array}{c}\text { Entrepreneurial } \\
\text { draw } \\
\text { (20) }\end{array}$ & $\begin{array}{c}\text { Voluntary } \\
\text { transfers } \\
\text { to labor } \\
\text { (Pensions, etc.) } \\
\text { (21) }\end{array}$ & $\begin{array}{l}\text { Contributions } \\
\& \text { gifts } \\
\text { (22) }\end{array}$ & $\begin{array}{l}\text { Non-monetary } \\
\text { gifts } \\
(23)\end{array}$ & $\begin{array}{l}\text { Bequests } \\
\text { (24) }\end{array}$ & $\begin{array}{c}\text { Autarkic } \\
\text { production } \\
(25)\end{array}$ & $\begin{array}{c}\text { Voluntary } \\
\text { transfers } \\
(26)\end{array}$ & $\begin{array}{l}\text { Voluntary } \\
\text { transfers } \\
\text { settled via } \\
\text { bank debits } \\
\text { (27) }\end{array}$ \\
\hline 1934 & 4,859 & 9,099 & 794 & 356 & 782 & 2,267 & 1,125 & 19,283 & 15,108 \\
\hline 1935 & 5,941 & 9,516 & 949 & 491 & 1,945 & 2,460 & 1,320 & 22,621 & 16,897 \\
\hline 1936 & 7,379 & 10,120 & 739 & 474 & 394 & 2,312 & 1,394 & 22,814 & 18,713 \\
\hline 1937 & 7,514 & 11,228 & 574 & 526 & 482 & 2,794 & 1,434 & 24,551 & 19,842 \\
\hline 1938 & 5,014 & 11,056 & 325 & 479 & 327 & 3,070 & 1,235 & 21,506 & 16,874 \\
\hline 1939 & 5,747 & 11,375 & 610 & 568 & 299 & 2,768 & 1,209 & 22,575 & 18,300 \\
\hline
\end{tabular}

Notes

(19) Taken from various editions of the Statistical Abstract for the years 1922-1939 from the tables entitled "Corporation Dividends." (The table number varies by year, but in 1922, for example, was Table No. 189.) The figures represent dividends paid by corporations, rather than NBER series A08185, "Dividends Received by Individuals," original source for NBER data, Kuznets (1941, Table 57:322-323), since corporations are also dividend recipients. The estimates for 1919 to 1921 are derived by applying the average ratio of dividends paid by corporations to dividends received by individuals (NBER series A08185) for the years 1922 to 1924, or 1.116, to the 1919-1921 values for NBER series A08185.

(20) From NBER series A08183, "Entrepreneurial Withdrawals.” Original source for NBER data, Kuznets (1941, Table 65:338-339).

(21) Voluntary transfers to labor include such payments as insurance claims and pension payments. They are estimated as the remainder of total transfers to labor (derivation described in Table A.2, column 13), less government-induced transfers to labor such as social security, work relief, and government pensions (derivation of the latter figures is described in Table A.5, column 31).

(22) Contributions and gifts are a composite of contributions reported on personal income tax returns and gifts of cash as reported on Federal Gift Tax Returns, as summarized in tables on Individual Income Tax, and Federal Gift Tax Returns in the Statistical Abstract (various editions).

(23) Non-monetary gifts represent voluntary transfers of stocks, bonds, real estate, and insurance as reported on Federal Gift Tax Returns, and summarized in the SAUS (various editions). Although, such gifts are likely to occur annually, and to some extent, irrespective of the tax treatment, gift tax data in the Abstract were only available for 1924-25 and 1932-39. Thus, this and the preceding gift tax component of transfers may be understated. However, because it is not possible to predict accurately the influence of tax treatment on the propensity of individuals to give voluntarily, estimates for years in which gift tax data were unavailable or when the gift tax was inapplicable were not made.

(24) Data on bequests are taken from the Federal Estate Tax return data as summarized in the SAUS (various editions). The values of estates from September 9, 1916 to January 15, 1922 were reported in the Abstract as a single figure. This figure was prorated to derive estimates for the years 1919 to 1921. The figures reported in column 24 represent the value of the gross estates of citizens and resident aliens. Although these data capture a significant portion (in dollar terms) of estate transfers, it is not complete. In its most binding form, the estate tax applied only to estates valued at more than $\$ 40,000$. Importantly though for the katallactic estimates resting on bank debits, the transfer of estates is assumed not to require the intermediation of the banking system, though undoubtedly some unknown portion of executors' fees, court costs, and some estate liquidations for example, might result in transactions that were effected through bank debits. Reliable data could not be found to suggest how much of bequests might so-involve the banking system, and as such, the assumption of treating all estate transfer as transfers of title to property has been assumed here for simplicity.

(25) See Table A.1, column 5.

(26) Voluntary Transfers $=(19)+(20)+(21)+(22)+(23)+(24)+(25)$.

(27) Voluntary Transfers Settled via Bank Debits $=(26)-(23)-(24)-(25)$. 
Estimates of Compulsory Transfer Activities

Table A.5. Compulsory transfers, 1919-1939.

\begin{tabular}{|c|c|c|c|c|c|c|c|}
\hline Year & $\begin{array}{l}\text { Government } \\
\text { revenues } \\
\text { (All levels) } \\
(28)\end{array}$ & $\begin{array}{c}\text { Government } \\
\text { expenditure } \\
\text { (All levels) } \\
\text { (29) }\end{array}$ & $\begin{array}{c}\text { Government } \\
\text { financing } \\
\text { activities } \\
\text { (30) }\end{array}$ & $\begin{array}{l}\text { Government- } \\
\text { induced transfer } \\
\text { to labor } \\
\text { (31) }\end{array}$ & $\begin{array}{c}\text { Compulsory } \\
\text { transfers } \\
(32)\end{array}$ & $\begin{array}{c}\text { Total voluntary } \\
\text { \& compulsory } \\
\text { transfers } \\
(33)\end{array}$ & $\begin{array}{c}\text { Total transfers } \\
\text { settled via } \\
\text { bank debits } \\
\text { (34) }\end{array}$ \\
\hline 1919 & 8,228 & 21,535 & 45,663 & 348 & 75,774 & 95,127 & 90,862 \\
\hline 1920 & 10,514 & 10,422 & 33,972 & 428 & 55,336 & 76,810 & 72,545 \\
\hline 1921 & 10,188 & 10,424 & 19,092 & 467 & 40,171 & 57,486 & 53,885 \\
\hline 1922 & 9,417 & 9,643 & 14,142 & 461 & 33,663 & 53,316 & 48,027 \\
\hline 1923 & 9,418 & 9,548 & 16,483 & 475 & 35,924 & 56,690 & 51,578 \\
\hline 1924 & 9,936 & 10,101 & 7,058 & 460 & 27,555 & 49,149 & 44,266 \\
\hline 1925 & 10,228 & 10,620 & 8,001 & 451 & 29,299 & 52,604 & 47,301 \\
\hline 1926 & 10,989 & 11,070 & 7,604 & 454 & 30,116 & 54,445 & 48,678 \\
\hline 1927 & 12,221 & 11,580 & 12,509 & 480 & 36,789 & 61,406 & 56,000 \\
\hline 1928 & 12,604 & 12,064 & 15,865 & 487 & 41,019 & 66,951 & 61,140 \\
\hline 1929 & 12,636 & 12,516 & 12,151 & 516 & 37,818 & 65,871 & 59,736 \\
\hline 1930 & 12,420 & 12,365 & 9,418 & 522 & 34,724 & 62,048 & 55,906 \\
\hline 1931 & 12,303 & 13,546 & 14,101 & 592 & 40,543 & 63,859 & 58,191 \\
\hline 1932 & 10,406 & 13,829 & 18,536 & 646 & 43,416 & 61,590 & 57,432 \\
\hline 1933 & 10,141 & 12,245 & 18,537 & 1,154 & 42,077 & 58,486 & 55,113 \\
\hline 1934 & 11,993 & 14,634 & 23,790 & 1,973 & 52,390 & 71,673 & 67,924 \\
\hline 1935 & 13,592 & 16,241 & 26,645 & 1,990 & 58,467 & 81,089 & 76,818 \\
\hline 1936 & 14,417 & 18,296 & 20,549 & 3,181 & 62,443 & 85,257 & 81,076 \\
\hline 1937 & 16,484 & 18,269 & 20,969 & 3,447 & 59,168 & 83,720 & 78,966 \\
\hline 1938 & 17,862 & 18,211 & 20,323 & 4,333 & 60,729 & 82,235 & 77,451 \\
\hline 1939 & 17,232 & 20,207 & 24,288 & 4,506 & 66,234 & 88,809 & 84,264 \\
\hline
\end{tabular}

(28) Equal to the sum of federal, state, and local government revenues from all sources. Federal revenues taken from the SAUS (1943, Table 258:242). Total state receipts figures for the years 1919, 1922-1932, and 19371939 taken from the SAUS (various years). Estimates of total state receipts for 1920-1921, relied on a straight-line extrapolation using the known 1919 and 1922 endpoints. Total state receipts for 1933-1936 were estimated by regressing total state receipts on total state tax revenues for the years 1919, 1922-1932, and 1937-1939. The resulting equation is given as, STRec $=-562.17+1.555$ (STTax), where STRec is total state receipts, and STTax is total state tax revenues. Using known state tax revenues from various editions of the SAUS, the equation was used to estimate total state receipts for 1933-1936.

Data on local government finances were far sparser than for higher-level governments. Revenue data were available for cities with populations of more than 30,000 inhabitants from the SAUS (various editions) for the years 1919, 1923-1924, 1926-1930, 1932-1936, and 1938. Data also were available on a total local government basis from various editions of the Statistical Abstract, for the years 1922, 1927, 1932, 1934, 1936, and 1938. Based on the relationship between these two data sets, it can be determined that from 1919-1926, cities with populations greater than 30,000 people accounted for roughly 51 percent of all local government revenues. This relationship allows estimates to be made for years in which city revenue data are available: Namely, 1919, 1923-1924, and 1926. Straight-line extrapolation was then used to fill in the missing estimates of total local government revenues for the years 1920-1922, and 1925. The relationship between total local government revenues and cities with populations greater than 30,000 changes in 1927, such that cities now account for about 47 percent of total local government revenues. This revised relationship was then used to estimate total local government revenues for 1928-1930. Beginning in 1931, the SAUS began 
Table A.5. (Continued).

reporting data on cities with populations greater than 100,000, and a complete set of these data are available for 1931-1939. To estimate total local government revenues for years in which total revenue data were missing (i.e., 1931, 1933, 1935, 1937, and 1939), the previous year's ratio of total local government revenue to revenues of cities with populations greater than 100,000 was applied to the current year for which an estimate was needed. Thus, to derive an estimate of 1931's total local government revenue, for example, the ratio of total local government revenue for 1930 to city revenues for 1930 was applied to the known value of city revenues for 1931. Subsequent years were estimated similarly.

(29) Equal to the sum of federal, state, and local government expenditures for all purposes. Federal expenditures taken from SAUS (1943, Table 258:243). Total state expenditure figures for the years 1919, 1922-1932, and 1937-1939 taken from the SAUS (various years). In 1919, for instance, state government receipts exceeded expenditures by 5.2 percent. In 1922, expenditures exceed receipts by 10.4 percent. Estimates of total state expenditures for 1920-1921, therefore, relied on a straight-line extrapolation of the deficit/surplus conditions prevailing between the known 1919 and 1922 endpoints, resulting in a balanced budget estimate for 1920, and an estimated net deficit of 5.2 percent in 1921. These surplus/deficit figures were then applied to the estimates of total state receipts estimated as described above in column 28. A similar methodology was employed to estimate total state expenditures for the years 1933-1936. The same data sources and estimating methodologies used to derive estimates of local government revenues, were used to estimate local government expenditures.

(30) To estimate the extent of government activities in the finance markets, the absolute dollar value of government bonds and other securities issued and retired in a given year are summed. Data on federal government bonds and other securities sale proceeds and retirements for 1919-1925 were taken from the SAUS (1925, Table 165:157), for the years 1926-1929 from the SAUS (1929, Table 217:216), for 1933-1938 from the SAUS (1938, Table No. 208:207), and for 1939 from SAUS (1943, Table 286:284).

To estimate state and local financing operations, the net increases or decreases in state and local debt outstanding was used as a proxy for this activity. The amount of debt outstanding for state governments is available from the SAUS (various years) for the years 1919, 1922, 1924-1932, and 1937. The volume of local debt is available from the SAUS for the years 1922, 1932, and 1937. For 1922 and 1932, the state government share of total debt outstanding remained static at 11 percent. This figure is thus used to determine the total amount of state and local government debt outstanding for the years in which state debt levels are known for the period 1919-1933. By 1937, state share of state and local debt outstanding rose to 14 percent of the total; so that from 1934 to 1937 the state share of total state and local debt outstanding was assumed to rise by one percentage point each year and then remain static at 14 percent for 1938 and 1939. The dollar value of the year-over-year change in state and local debt outstanding is the proxy used to estimate the volume of state and local financing operations. To determine the value for 1919, the difference between state and local government revenues and expenditures (see columns 28 and 29 above) was used. Although the net change method of determining state and local government financing activities will tend to understate the estimates for this activity, reliable data on state and local issuance and retirement of securities was not found. However, since a residual method is used to estimate finance katallactics, the understatement bias of state and local government financing activities will tend to lead only to a misclassification of this data as katallactic rather than as transfer activity rather than an omission of this activity as such. In either case, it remains a comparatively small component of financing activity and thus any bias should not significantly affect the results as presented.

(31) The difference between NBER series A08181a ("Wages, Salaries, and Other Payments to Employees," original source, Kuznets [1941, Table 57:322-323]) and A08181 ("Wages and Salaries Payments, Total," original source Kuznets [1941, Table 62:332-333]) yields an estimate of total transfer payments to individuals (labor) such as social security, workers' compensation, insurance, and private pension payments. The share that results from government-induced transfers to labor is estimated by summing government pensions, work relief payments, Social Security contributions of employers, Railroad Retirement System benefits payments, and state and local government social insurance payments as reported respectively in the SAUS (1943, Tables 258, 422, 422, 209:235, 384, 384, 196), and the HSUS (1976, vol. 1, Table H41:341). The sum of these five payments categories represents the estimate presented as compulsory transfers to labor.

(32) Compulsory Transfers $=(28)+(29)+(30)+(31)$.

(33) Total Transfers $=(32)+(26)$.

(34) Total Transfers Settled via Bank Debits $=(32)+(27)$. 


\section{Price Index Information}

Table A.6. Price indexes used to deflate nominal dollar estimates in preceding tables (For all indexes, $1925=100$.

\begin{tabular}{lccc}
\hline Year & $\begin{array}{c}\text { Index of } \\
\text { consumer prices (35) }\end{array}$ & $\begin{array}{c}\text { Index of } \\
\text { producer prices (36) }\end{array}$ & $\begin{array}{c}\text { Index of financial } \\
\text { asset prices (37) }\end{array}$ \\
\hline 1919 & 98.75 & 134.03 & 79.79 \\
1920 & 114.26 & 149.43 & 72.45 \\
1921 & 101.72 & 94.43 & 64.53 \\
1922 & 95.45 & 93.59 & 77.43 \\
1923 & 97.19 & 97.38 & 78.35 \\
1924 & 97.56 & 94.67 & 82.82 \\
1925 & 100.00 & 100.00 & 100.00 \\
1926 & 100.86 & 96.83 & 110.97 \\
1927 & 98.87 & 92.37 & 130.70 \\
1928 & 97.81 & 93.62 & 165.53 \\
1929 & 97.74 & 92.18 & 209.95 \\
1930 & 95.24 & 83.54 & 165.08 \\
1931 & 86.61 & 70.61 & 104.40 \\
1932 & 77.75 & 62.86 & 56.54 \\
1933 & 73.65 & 63.77 & 72.87 \\
1934 & 76.22 & 72.51 & 84.36 \\
1935 & 78.21 & 77.39 & 91.01 \\
1936 & 79.00 & 78.18 & 125.34 \\
1937 & 81.91 & 83.50 & 124.87 \\
1938 & 80.31 & 76.03 & 96.03 \\
1939 & 79.28 & 74.65 & 102.63 \\
\hline
\end{tabular}

Notes NBER Series M04128 (“Consumer Price Index, All Items, Bureau of Labor Statistics"). Index numbers of the original NBER/BLS series were recentered such that $1925=100$. This index was used as the divisor to deflate nominal estimates of Consumption Katallactics (Table A.1, column 6), Voluntary Transfers (Table A.4, column 26), and Compulsory Transfers (Table A.5, column 32).

(36) Annual average of monthly Bureau of Labor Statistics observations for the BLS Wholesale Price Index. NBER Series M04048 ("Index of Wholesale Price, Bureau of Labor Statistics"). Index numbers of the original NBER/BLS series were recentered such that $1925=100$. This index was used as the divisor to deflate nominal estimates of Production Katallactics (Table A.2, column 15), and nominal Production Wages (Table A.2, column 13)

(37) The index of financial prices was constructed from an index of stock prices and from an imputed index of bond prices. The stock price component of this index was constructed from an annual average of NBER Series M11025, "Index of All Common Stock Prices, Cowles Commission and Standard \& Poors Corporation." An index of bond prices was also constructed by inverting an evenly weighted average of high-grade and low-grade corporate bond yields (NBER Series M13035 "Yields on Corporate Bonds, Highest Rating" and M13036 "Yields on Corporate Bonds, Lowest Rating" respectively-original NBER source for both series, U.S. Department of Commerce, Survey of Current Business, November 1937). The stock and bond price components were recentered such that $1925=100$.

The bond price index based on bond yields is believed, through an opportunity cost of funds justification, to capture the pattern of other lending prices such as commercial bank loans, mortgages, and so on. The stock and bond price components of the index were weighted by their relative transactions volumes as given by NBER Series M11003 "Stocks, Value of Shares Sold on the New York Stock Exchange" and M11001 "Bond Sales, Par Value" (New York Stock Exchange). Equally weighted components produced a nearly identical price index.

This index was used as the divisor to deflate nominal estimates of Finance Katallactics (Table A.3, column 18). 


\section{Real Katallactic and Transfer Volumes}

Table A.7. Real katallactic \& transfer volumes. (Millions of Constant 1925 Dollars.)

\begin{tabular}{|c|c|c|c|c|c|}
\hline Year & $\begin{array}{c}\text { Real consumption } \\
\text { katallactics } \\
\text { (38) }\end{array}$ & $\begin{array}{c}\text { Real production } \\
\text { katallactics } \\
(39)\end{array}$ & $\begin{array}{l}\text { Real finance } \\
\text { katallactics } \\
(40)\end{array}$ & $\begin{array}{l}\text { Real voluntary } \\
\text { transfers } \\
(41)\end{array}$ & $\begin{array}{c}\text { Real compulsory } \\
\text { transfers } \\
(42)\end{array}$ \\
\hline 1919 & 50,767 & 159,327 & 138,354 & 19,599 & 76,736 \\
\hline 1920 & 51,703 & 141,715 & 208,719 & 18,794 & 48,430 \\
\hline 1921 & 52,133 & 140,983 & 275,707 & 17,023 & 39,493 \\
\hline 1922 & 55,354 & 194,041 & 235,316 & 20,591 & 35,269 \\
\hline 1923 & 61,114 & 266,167 & 152,163 & 21,366 & 36,962 \\
\hline 1924 & 64,184 & 273,849 & 185,416 & 22,134 & 28,245 \\
\hline 1925 & 63,030 & 242,394 & 254,280 & 23,305 & 29,299 \\
\hline 1926 & 68,106 & 246,007 & 260,421 & 24,121 & 29,860 \\
\hline 1927 & 69,402 & 253,053 & 278,227 & 24,899 & 37,210 \\
\hline 1928 & 72,446 & 257,474 & 308,836 & 26,514 & 41,940 \\
\hline 1929 & 75,328 & 265,993 & 317,928 & 28,703 & 38,694 \\
\hline 1930 & 74,517 & 216,117 & 254,964 & 28,689 & 36,459 \\
\hline 1931 & 67,585 & 177,896 & 272,534 & 26,920 & 46,810 \\
\hline 1932 & 59,379 & 132,211 & 296,360 & 23,375 & 55,840 \\
\hline 1933 & 60,554 & 152,712 & 168,028 & 22,281 & 57,133 \\
\hline 1934 & 67,533 & 165,364 & 141,788 & 25,298 & 68,732 \\
\hline 1935 & 66,978 & 181,850 & 147,855 & 28,922 & 74,753 \\
\hline 1936 & 72,757 & 230,128 & 115,649 & 28,876 & 79,037 \\
\hline 1937 & 78,063 & 231,855 & 102,663 & 29,974 & 72,237 \\
\hline 1938 & 78,902 & 218,275 & 94,579 & 26,777 & 75,615 \\
\hline 1939 & 84,018 & 255,757 & 71,690 & 28,477 & 83,547 \\
\hline
\end{tabular}

Notes

(38) Table A.1, column $6 \div$ Table A.6, column 1.

(39) Table A.2, column $15 \div$ Table A. 6 column 2 .

(40) Table A.3, column $18 \div$ Table A.6, column 3

(41) Table A.4, column $26 \div$ Table A.6, column 1 .

(42) Table A.5, column $32 \div$ Table A.6, column 1 .

\section{Acknowledgments}

I thank Richard E. Wagner, David M. Levy, Jerry S. Hanweck, Peter J. Boettke, Steven Horwitz, Tim Reichart, Susan E. Dudley, and the participants at the 1999 Southern Economic Association meeting for valuable comments on earlier drafts of this paper. The comments of two anonymous referees are also gratefully acknowledged. Any remaining errors are solely my responsibility. 


\section{Notes}

1. Young (1928), for example, was able to anticipate the modern strand of the increasing returns growth literature by nearly seven decades by drawing upon Smith's observation.

2. I have adopted here the practice in Levy $(1999: 1, n$. 1) of spelling katallactics with a "k" rather than the more modern "c." In addition to the justifications for this approach as appear in Levy (1999), it has an etymological justification; in that, the Phoenician "kaph"- the historical antecedent to our modern "k"-was essentially a "k" laid on its back, and symbolized the hollow of the hand or an upright palm. [Source: American Heritage Dictionary of the English Language, New Collegiate Edition (1976).] The Phoenician "gimel," the predecessor of our modern "c," on the other hand, symbolized a camel, or an object of wealth. The kaph thus recalls the process of voluntary exchange and symbolizes what Hayek (1976:108) recognized as a deeper meaning of "the Greek verb katallattein (or katallassein) which meant, significantly, not only 'to exchange' but also 'to admit into the community' and 'to change from enemy into friend."'

3. McKinnon (1992:32) summarizes Hayek's katallaxy as "the cash nexus linking firms and households..." Under a system of full collective ownership of all property, this cash nexus per se' would not emerge, since exchange as the term is used here presupposes ownership of and alienable rights in property.

4. The allusion of course is to Hirschman (1970).

5. Being anthropocentric, however, does not mean that a katallactic approach is anthropomorphic. That is, even though seemingly collective outcomes emerge from the millions of individual actions taken in the marketplace, this fact does not imbue a market with a will, ends, or means of its own. While it is possible to think of a market as a physical space—-such as a grocery store, or stock exchange—-the "market," as the term is used in this paper, simply refers to the abstraction that emerges out of the observation of two or more individuals trading to achieve their own ends. The market in short is not an organism. Individuals and only individuals evaluate and exchange, and although as observers of this process, we may aggregate and analyze these individual transactions, the basic individualistic nature of the process must not be lost, if we are to avoid error.

6. One need only consult the business pages when the quarterly gross domestic product (GDP) figures are announced (or a standard macroeconomics textbook) to hear the oft-heard suggestion that GDP, or its main component, consumption expenditure, constitutes the bulk of economic activity. For example, Eric Convey (2001) of The Boston Herald writes, following the release of weak third quarter 2000 GDP figures, "But so far, consumers have propped up the economy - and their spending accounts for two-thirds of GDP." Elsewhere in the article, Mr. Convey refers to GDP as "the broadest measure of economic activity." Mr. Convey is not alone. Paul Berry (2001) of The Washington Post, similarly notes that, "Many analysts follow changes in consumer confidence for clues about future consumer spending, which accounts for two-thirds of the nation's economic activity." Nor is this misperception limited to journalists. Many of the economists cited in these and other articles indicate a similar sentiment. This is unsurprising inasmuch as it parallels the standard textbook treatment of GDP and other measures of national income and product. See, for example, Hall and Taylor (1993:6, 31, and 268) for textbook treatments of the alleged importance of consumer spending and its relation to total economic activity, as against final demand.

7. That consumption constitutes a high percentage of GDP is subsumed in the derivation of the data and in the definitions of terms. This is uncontroversial, although it can lead to misapprehensions if extended to activity. The two terms are not synonymous. GDP is concerned with the net production of wealth aimed at final consumption. Economic activity, on the other hand, as the term is used in this paper, is concerned mainly with the katallaxy-i.e., with the nexus of voluntary exchanges that actually bring such wealth into being.

8. In this connection, see also, John Stuart Mill (1871 [1909]:79-81) in which he suggests,

What supports and employs productive labour, is the capital expended in setting it to work, and not the demand of the purchasers for the produce of labor when completed....

... It is, to common apprehension, a paradox; and even among political economists of reputation, I can hardly point to any, except Mr. Ricardo and M. Say, who have kept it constantly and steadily in view. Almost all others occasionally express themselves as if a person who buys commodities, the produce of labour, was an employer of labour, and created a demand for it as really, and in the same sense, as if he bought the labour itself directly, by the payment of wages. 
9. Irving Fisher's famous equation of exchange $(\mathrm{MV}=\mathrm{PT})$ can also be loosely thought of as a katallactic approach to economic activity as the term katallactic is used in this paper. The " $T$ " term represents in some sense transactions volumes, though Fisher's explication suffers from a lack of clarity. There are other weaknesses too in Fisher's exposition, but the interested reader is directed to Anderson (1917:135-149, and passim) where the equation of exchange is meticulously analyzed. However, for purposes here, in Anderson's (1917:143) extensive discussion of the "T" element, he reminds us that, "It should be noted that "volume of trade,' as frequently used, means not numbers of goods sold, but the money-price of all goods exchanged, or PT. It is in this sense of 'trade' that bank clearings are supposed to be an index of volume of trade." Indeed, that is the sense too in which exchange or katallactic activity, as developed in this paper, most closely parallels Fisher's formulation. (I thank an anonymous referee for suggesting the Fisherian parallel.)

10. Exploration of this latter point, while important, is beyond the scope of this paper.

11. That is, the requirements of an exchange allow one to differentiate exchanges from the mental processes of optimization and choice on the one hand, as well as from the actions involved in resource transfers on the other. In the former instance, exchange presupposes optimization and choice. In the latter, although both transfers and exchanges can entail the movement of goods among individuals (and also may include optimization and choice), transfers lack certain characteristics that exchanges share in common.

12. See Mises [1966 [1949]:194-195 and passim) where he equates action as such with the exchange of one state of affairs for another. While this conception of action can be useful, especially in distinguishing solipsistic maximizing from social exchange, it is an overly broad usage of the term as far as this paper is concerned. Indeed, The Oxford English Dictionary suggests that the Misesian usage of exchange may be "more correctly expressed by change: [as in the] [s]ubstitution of one person or thing for another." The terminology used in this paper that most closely parallels Mises' autistic exchange conception is "transfer," which describes the movement of goods in time or between individuals that need not entail reciprocity. See The Oxford English Dictionary (OED) entry (I.6.) for "exchange." OED accessed via the Electronic Text Center at the University of Virginia, http://etext.lib.virginia.edu/etcbin/oedbin/oed2.

13. Oxford English Dictionary, "exchange" entry, (I.1.).

14. "Entrepreneurial withdrawals [or draw] are the amounts retained by entrepreneurs for their own consumption and for investment outside their own firms." Kuznets (1941:82)

15. See Wagner (1989:3 and passim) for a discussion of governmental activities including transfers and the provision of public goods.

16. See, for example, Buchanan (1991) for a discussion of establishing the constitutional rules of the game. In addition, this cleavage between private markets and the polity necessarily rules out assertions that politics in fact (as against in theoretical abstraction) is just another market. For an approach that treats markets and the polity as essential equivalents see, for example, Stigler (1992).

17. Leaving aside the imprecision of whether markets per se' can fail or whether only individuals can fail, market failure arguments still must surmount the logical hurdle that a market has failed when such a market cannot form in the first place owing to indefensible property rights and thus to an inability to trade. Failure, in other words, presupposes the existence of that which subsequently fails. Public goods and externalities more broadly, might, therefore, be more accurately termed non-market outcomes, as against market failures. Regardless of whether one refers to government activities as transfers, or non-market outcomes, or something else again is of lesser moment, however, than that such government activity can be segregated for separate analytical treatment.

18. Wagner (1989:3).

19. While this approach potentially sacrifices some precision, it retains the virtue of simplicity, and the documentation provided in the appendix should easily accommodate alternative definitions. Government-induced transfers, moreover, will be classified as compulsory transfers to distinguish them from voluntary transfers such as gifts, bequests, or dividends.

20. The estimates that will be developed using bank debits data are first constructed using data in current dollars. Once the nominal estimates have been derived and classified, they are then deflated using applicable price indexes. The Appendix contains information on the estimating procedures and price indexes applied.

21. Then, to allocate exchange activities among the consumption, production, and finance categories, various components of the national income accounts, as well as corporate and entrepreneurial incomes and revenues are used, as documented in the associated Appendix. Estimates presented in the Appendix are in current 
dollars that are then deflated using the price indexes shown in the last table of the Appendix to generate the graphs shown in the various figures throughout the main text.

22. It is true that from 1850 to 1950 , non-bank intermediation (i.e., of insurance, trusts, pension funds, etc.) was growing relative to commercial bank intermediation, as documented for example, by Gurley and Shaw (1957). However, the residual approach used here to estimate the level of finance katallactics (described below and in the associated Appendix) implicitly includes the intermediation activities of non-banks to the extent payment for such non-bank intermediation services eventually settled through the presentation of traditional bank drafts.

23. Garvy (1959:65) suggests, for example, that the volume of debits outside New York closely approximates the value of final output. "Check payments for final products and payments to the factors of production alone add up to roughly twice the value of the GNP, even though some payments are made in currency." This makes sense inasmuch as checks are paid to the factors of production (i.e., the national income side) as well as to the products of final consumption (i.e., the GNP side). If New York debits involve predominantly financial exchanges, then any remainder (i.e., non-New York debits) may represent exchanges for production and or consumption activities.

24. Monthly bank debits data are available from the National Bureau of Economic Research (NBER) Macrohistory Database. NBER Series M12030 is the Total U.S. bank debits series, while NBER Series M12016 is the outside series. New York City debits are simply the difference between M12030 and M12016. The NBER Macrohistory database is available at http://www.nber.org/databases/macrohistory/contents.

25. Indeed cash can circulate several times in hand-to-hand exchanges before being re-deposited into the banking system and thus showing up in the bank debits data.

26. With respect to squaring katallactic volumes with other estimates of economic activity, including the National Income and Product Accounts, the inclusion of agricultural home production is a large contributor to consumption activity that would not appear in bank debits. However, such household production does not satisfy the definition of exchange activity described earlier, and so is excluded from this analysis.

In addition, non-bank intermediated currency expenditures for consumption can lead to a biasing of the estimates for consumption transactions. That is, currency used in consumption exchanges could change hands several times before re-contacting the banking system. However, Anderson (1917: 399) cites Kinley's study that "... a high percentage (very conservatively estimated by Kinley at from 50 to 60\%) of retail business is done with checks..." Kinley's estimate was for 1909. This figure no doubt rose as the U.S. system of payments became more sophisticated in interwar years given that hand-to-hand currency transactions can pose comparatively high transactions costs. Moreover, the small sums typically involved in such transactions, will eventually resurface in the banking system in any case as deposits from retail merchants and consumers. An estimate of non-bank intermediated currency transactions is therefore included when determining consumption katallactics and is described further below.

27. We have no way to estimate directly the amount that small retail firms paid to workers directly out of the till. This will not prove necessary, however, as reliable estimates for the total payment of wages of all types are available, and these data will be used instead to facilitate estimates of production Katallactics.

28. See Garvy (1959:19).

29. Machlup (1940:376-81, Tables XIII and XIV) estimated that internal stock clearing by the New York Stock Exchange obviated between 69 and 85 percent of check volumes in New York stock trade settlements from 1925 through 1938. Whether similar patterns obtained at other stock exchanges outside New York is unknown. In any case, estimates of financial exchanges that rely on bank debits data alone are likely to be understated because of such non-bank clearing activities.

30. An alternative approach to check the estimate arising out of bank debits for financial exchanges would be to sum up the dollar value of trading activities at the various stock and bond exchanges (i.e., the New York, the American, and the regionals), as well as the dollar values of traded commodities contracts at the Chicago, Kansas City, and other exchanges, and the dollar volume of credit contracts entered into through the various outlets of the banking system. Unfortunately, this approach suffers from at least two main deficiencies. First, the data are not available in any complete form. Some of the major exchanges do provide data from which a partial estimate could be constructed, but many of the smaller exchanges do not. Second, this approach would still omit private contracts such as swap agreements or private granting of credit, and as such would still suffer from bias, though from a somewhat different perspective. 
31. See, for example, Gurley and Shaw (1956:262-264).

32. See for example Samuelson (1992:416) for the textbook exposition of the imputed nature of final product. On the one hand, Samuelson states, "GNP equals the sum of money values of all consumption and investment goods, government purchases, and net exports to other lands." His definition seems to indicate a comprehensive measure of economic activity. However, three pages later, the intermediate goods represented by investment, we are told, should be netted out to avoid so-called double counting. "If you look again at the upper loop [in the standard circular flow diagram], you will see that bread and cars appear in the flow of products, but you will not find any wheat, flour, or steel." (p. 419) This view is fine if one's concern is with value added, or plutology. If however, one's focus is instead on katallactic activity, this view can be misleading.

33. General equilibrium models suggest that a focus on either the asset or the liability side is appropriate. As far as the assumptions of general equilibrium go, this is an acceptable simplification. However, if the basic principles of sound finance are violated (say, by ignoring the matching principle), then a persistent liability imbalance may result that leads to bankruptcy. This condition is particularly dangerous when it applies to bank assets and liabilities. Moreover, if the future is uncertain, then a focus on the balance sheet in its entirety is mandatory since mistakes on either side of ledger can lead to an out-of-balance condition that must be corrected.

34. Anderson (1917:224).

35. Anderson (1917:227), however, asserts just the opposite when he claims:

But quite apart from speculation, it is not true that trade is a mere matter of physical capacities and technique, a passive function of production. Rather, one would almost have to reverse the relation. Production waits on trade!

Production, as now carried on, is primarily conducted in the expectation of sale, and of profitable sale.Trade does not go of itself, automatically. Rather, it is a highly difficult matter, calling for the highest order of ability, and the labor of innumerable men. In general, I think it safe to say that in ordinary times, the manufacturer loses vastly more sleep over the question of how he shall market his output, than he does over the question of how he shall produce it.

36. Kuznets (1946:13) formally defines consumer outlay as, "In both the present and earlier derivation, the flow of goods to consumers is in essence the difference between national income (measured by the flow of incomes approach) and net capital formation (measured independently)."

37. This figure also includes royalty income, but for simplicity's sake, we shall abstract from the royalty aspect and consider the figure as depicting rents only. The rental income component of national income is available as NBER Macrohistory series A08184, "Net Rent Received by Individuals." NBER takes this figure from Kuznets (1941, Table 57:322-323).

38. See Kuznets (1941, Table A1, col. 1:546).

39. The value of farm products consumed in farm households is taken from the Historical Statistics of the United States (1976, Table K269:483).

40. Currency-based transactions are accomplished by presentation of minor coin, paper currency (i.e., Federal Reserve or Treasury notes), or gold coin. Publicly held currency appears as NBER series M14125, "Currency Held by the Public, Seasonally Adjusted." NBER's original source is Friedman and Schwartz (1970, Table 27, col. 3:402-415).

41. That is, consumer outlay - the unadjusted Kuznets (1941) figure, as presented in NBER series A06073divided by M1 yields M1 consumer outlay velocity. M1 is derived by adding demand deposits (NBER series M14172) to Currency Held by the Public, described in the preceding note.

42. Table A.1 in the Appendix presents the nominal data underlying Figure 1 in tabular form, as well as the data sources, and estimating procedures used to construct the graph. Table A.6 documents the consumer price index used to deflate the nominal data presented in Table A.1 and to generate the current dollar presentation of Figure 1. Table A.7 summarizes the real estimates for each katallactic and transfer category.

43. In deflating the nominal estimates, I remain aware of the myriad problems associated with index numbers and the blurring that can occur when using averages to deflate aggregate series. Nevertheless, since the focus in this paper is on actual economic activity, and the index deflation process is a standard method for at least inferring an underlying real patterns, the nominal estimates of consumption katallactics derived as described in the text 
are deflated using the Bureau of Labor Statistics (BLS) Cost of Living Index (NBER Series M04128, "United States, Index of Cost of Living, BLS"). The original BLS index was recentered such that $1925=100$.

44. Firms also reported other income sources such as rent, interest, and dividends that combined with operating revenues (revenues earned from a firm's principal lines of business) generate gross receipts. The focus here is on operating revenues. Also, a relatively small portion of operating revenues and costs consist of exports and imports, but for simplicity, assuming all trade takes place domestically ignores this complication. While adding the additional category of foreign trade may improve precision slightly, the focus here is not on precise classification, but rather on general patterns of katallactic activity at a relatively high level of abstraction. In this connection, observe that from 1919 to 1939, net exports averaged \$918 million per year, while total foreign trade (exports plus imports) annually averaged \$7.1 billion (NBER series M07023, "U.S. Total Exports" and NBER series M07028, "U.S. Total Imports"). Total foreign trade thus amounted to less than three percent of average annual business revenues and even less of total katallactic activity. Of course, the presence of trade barriers-including the agricultural tariff of 1921, the 1922 Fordney-McCumber Tariff, and the Tariff Act of 1930, or "Smoot-Hawley"- diminished the importance of foreign trade in the U.S. during this period as well.

45. Such exchange activities among firms are crucial to the katallactic perspective, but are typically netted out in the process of formulating the National Income and Product Accounts. For a further contrast between the katallactic view and national income and product accounting, see below; however, it may be useful here to recall that Leontief (1936:110), when considering whether his input-output analysis produced double counting errors, argued that wider views of economic activity could be just as instructive as the net views provided by national income measures:

For the understanding of the economic structure of a business enterprise and evaluation of the prospects of its future development, even an approximate knowledge of the itemized expenditure and revenue account is more important than the most accurate information concerning the single figure given for its net revenue or deficit. The same is true regarding empirical analysis of the structure of the whole national economy. It is true that, from the point of view of welfare economics, the part of the annual flow of values which is more or less arbitrarily defined as the National Income deserves particular attention. To a more detached observer, however, it may appear to be a mere by-product of the whole highly complex process of production and distribution of economic values.

46. Reisman (1996:778-787) in fact suggests that it is just this difference-between the expenditures of capital goods purchasing firms, who depreciate their purchases over time, and capital goods selling firms who record the entire capital goods sale as revenue in the year it occurs-that constitutes an inherent "spring" to profitability that helps a capitalistic economy revive after period of slump. Policies that undermine capital accumulation, therefore, are likely to impede economic recovery.

47. For an early discussion of the value and potential pitfalls of the SOI data see Ebersole, Burr, and Peterson (1929). Kuznets (1941:96-132) also provides a good summary of the uses and shortcomings of the SOI data for construction of the national income accounts.

48. Government purchases of goods and services are estimated by summing total government expenditures at all levels and then subtracting gross government payment of wages and salaries. The remainder should approximate the dollar value of government purchases of goods and services. There is no distinction made here between durable and non-durable goods purchases of the government, or between munitions and other goods.

49. Depreciation also appears in a standard income statement, but insofar as it represents the return of (or accounting for) previous investments in capital, and no money changes hands, it is ignored. Current exchange activity for capital equipment is, however, accounted for in the total business-to-business revenue figure and it forms the basis of future depreciation charges in any case. With respect to interest payments by firms to the suppliers of capital and credit, such transactions are implicitly accounted for in the finance katallactics section below. Payments of dividends, draw, and taxes also appear on a standard income statement but these payments are considered transfers, because dividends and draw do not technically constitute an exchange as defined earlier, and taxes paid by firms are accounted for under compulsory transfers.

50. Wages and salaries of financial firms' employees belong in the finance katallactics category, while those of government employees belong in the compulsory transfer category. No complete estimates of wage payments 
made for consumption purposes could be found or reliably derived. Since this component of wage and salary payments is presumed relatively small in any case, its omission should not significantly bias the estimates.

51. The nominal estimates of production katallactics were deflated using the BLS Index of Wholesale Prices, recentered such that $1925=100$ (NBER Series M04048, "United States, Index of Wholesale Prices, BLS).

52. Nominally, total business revenues (including the revenues of financial services firms) declined in 1925 by 4.5 percent. Financial services firms' revenues — which are subtracted to determine production katallacticsincreased 25 percent owing to higher interest income. (Call money rates or the interest rate for short-time money, NBER Series M13001, "Call Money Rates, Mixed Collateral," rose from two percent in summer 1924 to over 5 percent near year's end 1925 for example.) The net effect of these two influences was to lower nominal production katallactics by 6.5 percent. 1925 also saw a 6 percent rise in producer prices, the largest increase in wholesale prices since 1920, and the largest increase of the decade. Combining these two effects produces the 11.5 percent decline in real production katallactics for 1925 .

53. The figure for real wages is the deflated value of nominal wages calculated as described in Appendix A, Table A.2, column 13. The deflator used was the producer price index, Appendix Table A.6, column 2.

54. See also Rothbard [1983 (1963):281] and Schlesinger (1965) for more discussion of the various high wage policies pursued during the 1930s. One such policy mentioned by both authors was the de facto ban on immigration into the United States enacted by the Hoover State Department and effective as of September 1930. The ban's purpose was to curtail increases in the supply of labor coming from foreign sources and thus to keep domestic wage rates elevated. The effects of the various high-wage policies were short-lived, if effective at all, inasmuch as real production wages eventually corrected sharply, falling 3.1 percent in 1931, 16.5 percent in 1932 , and 8.7 percent in 1933 .

55. Anderson [1979 (1949)]:439-469), for example, suggests this secondary depression was largely brought on by a combination of ill-advised tax and wage policies, and possibly aggravated by poor monetary decisions at the Federal Reserve-though he tends to dismiss this latter influence.

56. The derivation of the transfer estimates appears in the Appendix, Tables A.4 and A.5.

57. As noted above in connection with the discussion on inside debits (notes 28 and 29), Garvy (1959:19) estimated that had checks been presented instead of directly clearing stocks through the Stock Clearing Corporation, "New York clearings for 1921-1946 would have increased on the average by about 12 per cent." Applying the estimate of trades cleared via the Stock Clearing Corporation (as appear in the Appendix, Table A.3, column 17) against inside debits (i.e., Total Bank Debits, NBER series M12030 less Outside Debits, NBER series M12016a) produces an average New York City check obviation rate of 10.2 percent for 1921-1939, which is in line with Garvy's estimates.

58. For the construction of the financial assets price index, see Appendix A, Table A.6, column 37.

59. Generally speaking, and laying aside issues of malinvestment, in keeping with law of non-satiation, increases in either consumption or production goods are unambiguously favorable. Their increases imply rising real incomes and therefore an improving standard of living.

60. The changes in prices that are noted in the text are calculated using the constructed financial asset price index described in the Appendix, Table A.6, column 37, and reflect year-over-year percentage changes.

61. The important point for purposes here is not the naming convention per se', but rather the recognition of the interdependency of price and volume patterns for interpreting real finance Katallactics.

62. Confidence in financial markets was partially restored in early 1930 as documented by Anderson [1979 (1949): 223]. However, following the passage of the Tariff Act of 1930 ("Smoot-Hawley") in the summer of 1930, Anderson [1979 (1949):227-230] recounts a sharp break in asset prices from which recovery essentially would not be made until 1932.

63. The "personal" qualifier reflects the fact that these particular transfers of resources involve the property of the person in question, as against its permanent relinquishment. It is only the temporal assignment of the resources that shifts.

64. For example, household production provided by household members—such as lawn mowing, babysitting, or gardening-has economic content, but lacks the interpersonal characteristics of exchange as used here (assuming the household is the economic unit in question). Moreover, such production is notoriously difficult to quantify with any precision. On this latter point, see Kuznets (1941:9-11 and passim).

65. See, for example, Treasury Secretary Mellon's (1924) analysis of the mid-1920s tax reforms.

66. The relative share of dividends and draw in voluntary transfers would continue to fall through 1935. 
67. For a discussion of the Austrian structure of production see, for example, Böhm-Bawerk [1959 (1889): 102-118 and passim], or Hayek [1967 (1931):32-68].

68. For more on the concept of malinvestment, see, for example, Mises [1966 (1949): 394 and passim].

69. Anderson [1979 (1949):151-157, and 182-191] identifies three major open market operations conducted by the Federal Reserve System (1922, 1924, and 1927) that he classifies as creating excess credit. He suggests most of this excess credit creation spilled into financial assets rather than directly into the physical structure of production - a conclusion that is partly supported by the preceding discussion of real financial katallactics. However, the sharp growth of production relative to consumption shown in Figure 5 seems to suggest that perhaps some of this credit—particularly from the first two operations-may have gone into the structure of production, as well as into financial assets.

70. See Anderson [1979 (1949):366 and passim] for a fuller discussion of the economically disturbing properties of the changed inheritance and estate tax regimes.

71. Anderson [1979 (1949):372]

72. Anderson [1979 (1949):376], recounts a Treasury spokesman at Senate committee hearing testifying that, "We [in the Roosevelt Administration] also have some ground for suspecting that the accumulation of these very corporate surpluses assisted materially in causing the depression."

73. Anderson [1979 (1949):381].

74. Recall that production katallactics include exchanges for capital goods, materials, and the purchase of business services. Using Kuznets (1961) current dollar estimates for gross capital formation (NBER Series A10037, "United States, Gross Capital Formation, Total, in Current Prices, 1919-1939”), and deflating them into 1925 dollars, suggests that capital goods-related exchanges amounted to between 4 and 10 percent of real production katallactics during the interwar years. Similarly, real wages amounted to roughly 20 percent of production katallactics, while services revenues and business rents equated to about 3 percent of production katallactics. This suggests that roughly two-thirds of production katallactics involve materials and non-capital equipment consumed in the process of production. Admittedly, these are only very general indications of magnitude, but they are nevertheless seem to indicate that the netting process of national income and product accounts omits a significant volume of economic activity in their formulation and measurement.

75. By comparison, deflating Kuznets (1941, Vol. 1:322, Table 58) national income estimates (also as NBER series A08167, "National Income in Current Prices") into 1925 dollars, produces a national income estimate that averaged roughly \$73 billion from 1919 to 1938 .

\section{References}

Anderson, B. M. (1917) The Value of Money. New York: MacMillan \& Co. (Undated reprint, Grove City, Pennsylvania: Libertarian Press, Inc.)

Anderson, B. M. (1979 [1949]) Economics and the Public Welfare: A Financial and Economic History of the United States, 1914-1946. Indianapolis: Liberty Press.

Baumol, W. (1959) Business Behavior, Value, and Growth. New York: MacMillan.

Berry, J. M. (2001) "Consumer Confidence Fell Again in November.” The Washington Post. November 28, p. E04.

Board of Governors of the Federal Reserve System (1943) Banking and Monetary Statistics, 1914-1941.

Washington: Board of Governors of the Federal Reserve System.

Böhm-Bawerk, E. (1959 [1889]) Capital and Interest, Book II, Positive Theory of Capital. Translated by G. D. Huncke and H. F. Sennholz. South Holland, Illinois: Libertarian Press.

Buchanan, J. M. (1975) “A Contractarian Perspective for Applying Economic Theory." American Economic Review, 65(2): 225-230.

Buchanan, J. M. (1979) What Should Economists Do? Indianapolis, Indiana: Liberty Press.

Buchanan, J. M. (1988) “Contractarian Political Economy and Constitutional Interpretation.” American Economic Review, 78(2): 135-139.

Buchanan, J. M. (1991) “Constitutional Economics.” In: Eatwell, John et al. (Eds.) The New Palgrave: The World of Economics, pp. 134-142. New York: W.W. Norton \& Co., Inc. 
Buchanan, J. M and Yoon, Y. (1994) "Increasing Returns, Parametric Work-Supply Adjustment, and Work Ethic." In: Buchanan, J. M and Young, Y. (Eds.) The Return to Increasing Returns, pp. 343-358. Ann Arbor: University of Michigan Press.

Convey, E. (2001) "U.S. Economy Nears Brink." The Boston Herald, November 1: 039.

Ebersole, J. F. et. al. (1929) "Income Forecasting by the Use of Statistics of Income Data." Review of Economic Statistics, 11(4): 171-196.

Friedman, M. and Schwartz, A. J. (1970) Monetary Statistics of the United States: Estimates, Sources, Methods. New York: National Bureau of Economic Research.

Garvy, G. (1959) Debits and Clearings Statistics and Their Use. Washington: Federal Reserve Board of Governors.

Gurley, J. G. and Shaw, E. S. (1956) "Financial Intermediaries and the Saving-Investment Process." Journal of Finance, 11(2): 257-276.

Gurley, J. G. and Shaw, E. S. (1957) “The Growth of Debt and Money in the United States, 1800-1950: A Suggested Interpretation." Review of Economics and Statistics, 39(3): 250-262.

Hall, R. E. and Taylor, J. B. (1993) Macroeconomics: Theory, Performance, and Policy, 4th edn. New York: W. W. Norton \& Co.

Hayek, F. A. (1967 [1931]) Prices and Production. New York: A. M. Kelley Publishers.

Hayek, F. A. (1976) Law, Legislation, and Liberty, Vol. 2: The Mirage of Social Justice. Chicago: The University of Chicago Press.

Hayek, F. A. (1988) The Fatal Conceit: The Errors of Socialism, Bartley, W.W. (Ed.). London: Routledge.

Hirschman, A. O. (1970) Exit, Voice, and Loyalty: Responses to Decline in Firms, Organization, and States. Cambridge, Massachusetts: Harvard University Press.

Kuznets, S. (1941) National Income and Its Composition, 1919-1938. New York: National Bureau of Economic Research.

Kuznets, S. (1946) National Product Since 1869. New York: National Bureau of Economic Research.

Kuznets, S. (1961) Capital in the American Economy: Its Formation and Financing. London: Oxford University Press.

Leontief, W. W. (1936) "Quantitative Input and Output Relations in the Economic Systems of the United States." Review of Economics and Statistics, 18(3): 105-125.

Levy, D. M. (1992) The Economic Ideas of Ordinary People: From Preferences to Trade. London: Routledge.

Levy, D. M. (1999) "Katallactic Rationality: Exploring the Links between Cooperation and Language," American Journal of Economics and Sociology, 58(4): 729-747.

Machlup, F. (1940) The Stock Market, Credit and Capital Formation. London: William Hodge \& Co.

McKinnon, R. I. (1992) “The Road Back from Serfdom: A Tribute to Friedrich A. Hayek.” American Economic Review 82(2): 31-36.

Mellon, A. W. (1924) Taxation: The People's Business. New York: The MacMillan Co.

Mill, J. S. (1909 [1871]) Principles of Political Economy, Seventh Edition. New York: Longmans, Green, \& Co.

Mises, L. (1966 [1949]) Human Action: A Treatise on Economics, 3rd Revised Edition. Chicago: Contemporary Books.

National Bureau of Economic Research, NBER Macrohistory Database. Available on-line at http://www.nber.org/databases/macrohistory/contents.

Quesnay, F. (1972 [1758]) Tableau Economique. Translated by M. Kuczynski et al. New York: A.M. Kelley Publishers.

Reisman, G. (1996) Capitalism: A Treatise on Economics. Ottawa, Illinois: Jameson Books.

Rothbard, Murray N. (1983 [1963]) America's Great Depression. New York: Richardson \& Snyder.

Samuelson, P. A. and W. D. Nordhaus (1992) Economics 14th edition. New York: McGraw-Hill, Inc.

Schlesinger, Arthur (1965) The Age of Roosevelt: The Crisis of the Old Order, Sentry edition. Vol. 1. Boston: Houghton Mifflin Co.

Smith, A. (1991 [1776]) An Enquiry Into the Nature and Causes of the Wealth of Nations. New York: Alfred A. Knopf.

Smith, A. (1978 [1762]) Lectures on Jurisprudence, Glasgow Edition. R.L. Meek et al. (Eds.), New York: Oxford University Press.

Smith A. [1956 (1763)] Lectures on Justice, Police, Revenue and Arms. Cannan, E. (Ed.) New York: Kelley \& Millman, Inc. 
Stigler, G. (1951) “The Division of Labor is Limited by the Extent of the Market." Journal of Political Economy, 59(3): 185-193.

Stigler, G. (1992) "Law or Economics?” Journal of Law and Economics, 35(2): 455-468.

United States Department of Commerce, Bureau of the Census (1976) Historical Statistics of the United States, Colonial Times to 1970. Washington, DC: United States Government Printing Office.

United States Department of Commerce, Bureau of the Census (1919-1943) Statistical Abstract of the United States. Washington, DC: United States Government Printing Office.

Vedder, R. and Gallaway, L. (1993) Out of Work: Unemployment and Government in Twentieth-Century America. New York: Holmes \& Meier.

Wagner R. E. (1989) To Promote the General Welfare: Market Processes vs. Political Transfers. San Francisco: Pacific Research Institute for Public Policy.

Whately, R. (1966 [1832]) Introductory Lectures on Political Economy, Second Edition. New York: Augustus M. Kelley.

Young, A. (1928) “Increasing Returns and Economic Progress.” Economic Journal, 38(152): 527-542. 